University of San Diego

Digital USD

Theses

Theses and Dissertations

Spring 5-15-2017

\title{
Larval rockfish diversity abundance dynamics in association with a marine protected area in the Southern California Bight
}

Dustin Chen

University of San Diego

Follow this and additional works at: https://digital.sandiego.edu/theses

Part of the Marine Biology Commons, Natural Resources and Conservation Commons, and the Oceanography Commons

\section{Digital USD Citation}

Chen, Dustin, "Larval rockfish diversity abundance dynamics in association with a marine protected area in the Southern California Bight" (2017). Theses. 21.

https://digital.sandiego.edu/theses/21

This Thesis: Open Access is brought to you for free and open access by the Theses and Dissertations at Digital USD. It has been accepted for inclusion in Theses by an authorized administrator of Digital USD. For more information, please contact digital@sandiego.edu. 


\title{
UNIVERSITY OF SAN DIEGO
}

\section{San Diego}

\author{
Larval rockfish diversity abundance dynamics in association with a marine \\ protected area in the Southern California Bight
}

\begin{abstract}
A thesis submitted in partial satisfaction of the requirements for the degree of
\end{abstract}

Master of Science in Marine Science

by

Dustin C. Chen

Thesis Committee

Andrew R. Thompson, Ph.D., Chair

Steven Searcy, Ph.D., Thesis Advisor

John R. Hyde, Ph.D.

David M. Checkley, Jr., Ph.D. 
The thesis of Dustin C. Chen is approved by:

Andrew R. Thompson, Ph.D., Thesis Chair

NOAA Southwest Fisheries Science Center

Steven Searcy, Ph.D., Thesis Advisor

University of San Diego

John R. Hyde, Ph.D., Thesis Committee Member

NOAA Southwest Fisheries Science Center

David M. Checkley, Jr., Ph.D., Thesis Committee Member Scripps Institution of Oceanography

\section{University of San Diego}

San Diego

2017

ii 
(This page intentionally left blank) 


\section{ACKNOWLEDGMENTS}

To my advisor, Andrew, thank you for all of your guidance, teaching, perseverance, and oversight these past three and a half years. When I was feeling unmotivated or discouraged and was just overall difficult to hang with you still hung in there with patience and kept pushing me forward. You are an A-class advisor, and I couldn't have done it without your support.

To my committee members, John, Dave, and Steve, thank you also for your oversight and input into the thesis. John, thank you especially for your help with the genetics work and troubleshooting the sequencing and identification process. Dave, thank you for continuing to mentor me even into your retirement and for also pushing me forward at various points in the project; I'm grateful to have had you as my mentor since undergrad.

To the NOAA Southwest Fisheries Science Center as a whole, I am grateful for being allowed to use the facilities to conduct this research. Russ, thanks for your words of insight into the project as well, and I'm really thankful that you made the decision those years ago to begin preserving mesozooplankton samples in ethanol, otherwise this whole project could never have been realized.

Funding for this project was made possible by a Fisheries and the Environment Grant (ID: 14-09). Partial funding for tuition and living expenditures came from graduate grants provided by the University of San Diego (USD), as well as a runner-up award from the Steven Berkeley Marine Conservation Fellowship. 
To others who have helped me on this project—Lian, Dereka, and Bryanthanks for helping me with all of the sorting, genetic ID work, and measuring that needed to be done. Lian especially, thank you so much for your work with all of that processing; you are a rock star in the lab.

To Mom, Dad, Derrick, and Melisa, thank you for your emotional and financial support throughout this program. It's been quite a long ride for sure, probably longer than you all expected, but thank you for sustaining me with your love and prayers. Thank you especially for voluntarily absorbing the bigger financial costs so that I can focus on the project without having to worry about how I'm going to support myself; I love you all very much!

To the friends I've made along the way-my colleagues at USD and at the larval lab at NOAA-SWFSC - thanks for the fun times and inside jokes and awkward moments (you know who you are) you've provided along the way that peppered this journey with smiles and laughter.

Finally and ultimately I give all thanks and praise to God, apart from Whom I can do nothing and through Whom I am forgiven, loved, sustained, and have hope for eternity. 


\section{TABLE OF CONTENTS}

List of Figures .....................................................................................

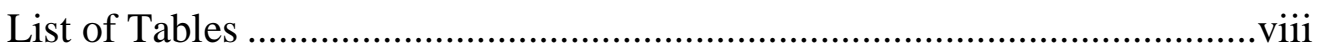

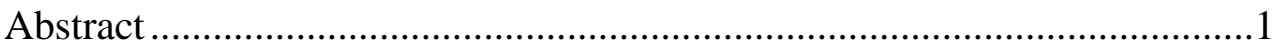

Chapter 1: Introduction

1.1 The Global State of Fisheries.....................................................

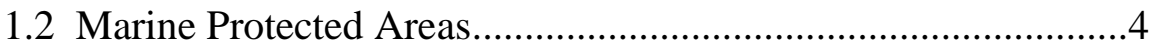

1.3 Rockfish Biology ...................................................................

1.4 The Rockfish Fishery in the Southern California Bight ..............9

1.5 Southern California Bight Oceanography ...................................11

1.6 Cowcod Conservation Areas.......................................................15

1.7 Questions and Hypotheses ........................................................17

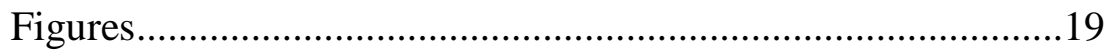

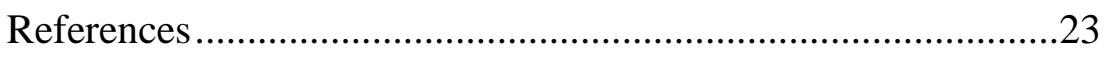

Chapter 2: Evidence of increased larval production from a southern California marine protected area

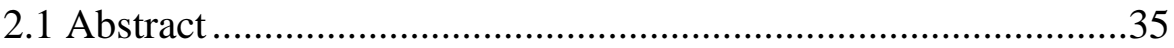

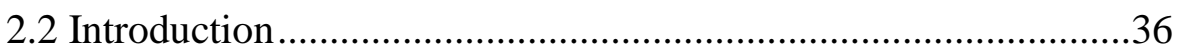

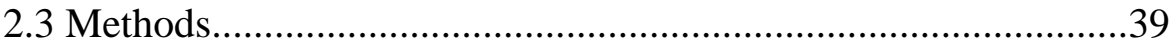

2.3.1 Sample collection and initial processing.............................39

2.3.2 Genetic identification and data refinement ..........................40

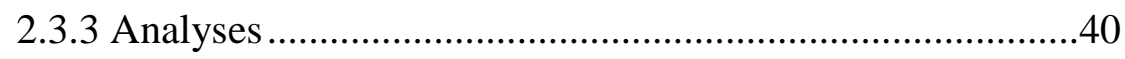

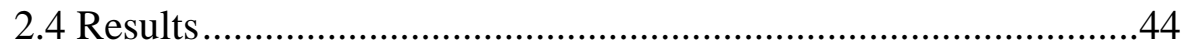

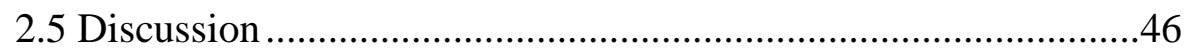

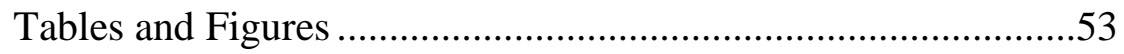

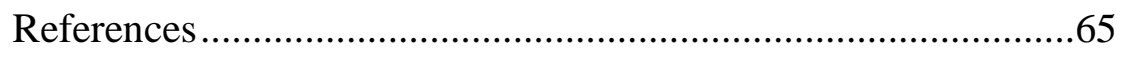

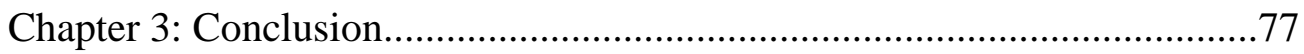

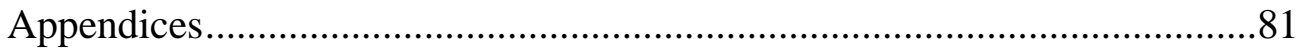




\section{LIST OF FIGURES}

Figure 1.1 The Southern California Eddy .................................................19

Figure 1.2 Map of the Southern California Bight .....................................21

Figure 2.1 Delta mean abundances of targeted rockfishes over time ...........57

Figure 2.2 Delta mean abundances of non-targeted rockfishes over time ....59

Figure 2.3 Average winter environmental variables over time......................61

Figure 2.4 Delta mean abundances of targeted species vs. CCA presence...63

Figure A.1 Histograms to assess for outliers ...............................................94

Figure A.2 Moran's I z-values to assess for spatial autocorrelation ..............96

Figure A.3 Temporal autocorrelation function values .................................99

Figure A.4 Two-way cluster analysis to determine CCA station pairs.........102

Figure A.5 Delta mean abundances of all rockfishes over time ....................104

Figure A.6 Logistic plots of rockfish species vs. temperature .......................106 


\section{LIST OF TABLES}

Table 2.1 Total abundances of most abundant species over time

Table 2.2 Rockfish species presence and environmental factors .................55

Table A.1 Correlations of environmental variables with each other............86

Table A.2 Larval abundances of all rockfishes ........................................8

Table A.3 Environmental model outputs for all species ...........................91 


\begin{abstract}
Marine protected areas (MPAs) are areas aimed at protecting natural and cultural resources that are often proposed as a way to alleviate the effects of overfishing on populations of targeted species; these areas have varying degrees of fishing and recreational use restrictions. In order to assess MPA efficacy, it is important to determine the mechanisms by which the presence of MPAs affect reproductive output within and potentially even beyond their boundaries. I attempted to address this through studying the responses of rockfish (Sebastes spp.) larval abundances to the presence of the Cowcod Conservation Areas (CCAs) located within the Southern California Bight region. Rockfish larvae were collected from mesozooplankton samples obtained during winter survey cruises by the California Cooperative Oceanic Fisheries Investigations (CalCOFI) program and identified by sequencing the cytochrome $b$ gene. I constructed timeseries of rockfish larval abundances within the Southern California Bight from 1998 to 2013.

I found that, not only have delta mean larval abundances of multiple rockfish species increased throughout the period, three historically-targeted species' delta mean larval abundances_-Bank Rockfish (S. rufus), Speckled Rockfish $(S$. ovalis), and Olive Rockfish (S. serranoides)—increased at a greater rate within the CCAs compared to locations with similar environmental parameters outside of the CCAs. This is the first decadal-scale study that explicitly demonstrates an increase in reproductive output from an MPA in the form of increased larval
\end{abstract}


abundances, thus contributing crucial information to the understanding of MPA efficacy.

Additionally, the dataset created during this study will become the basis for several future studies that will further elucidate the spatiotemporal dynamics of rockfish larvae within CCAs and in the Southern California Bight region as a whole. These studies will further contribute to understanding the efficacy of the CCAs in their facilitation of rockfish species recovery, as well as provide important information for rockfish fisheries management in the region. 


\section{CHAPTER 1: INTRODUCTION}

\subsection{The Global State of Fisheries}

It is now clear that overfishing has adversely impacted fish populations and ecosystems worldwide. Jackson et al. (2001) found that historical overfishing on a global scale led to ecological extinction of many targeted species and consequent changes in ecological communities, especially in coastal ecosystems. Myers and Worm (2003) showed that coastal region community biomass in 4 continental shelf and 9 oceanic systems was reduced by approximately $80 \%$ after 15 years of industrialized fishing, and they estimated that large predatory fish biomass was $10 \%$ of pre-industrial levels. In more recent studies, Pitcher and Cheung (2013) found that serious depletions and declining catch-per-unit-effort (CPUE) continue to be a recurring problem in fisheries worldwide, and Christensen et al. (2014) estimated that predatory fish biomass declined globally by $2 / 3$ from 1880 to 2007 . Furthermore, Christensen et al. (2014) found that the rate of decline still appears to be accelerating.

One example of an ecological impact of overfishing is the triggering of "trophic cascades," in which removal of an important species from a community, such as a large apex predator, has indirect far reaching repercussions for multiple trophic levels in the food web of that community (Andersen and Pedersen 2009). The Black Sea and Nova Scotian shelf are examples of ecosystems that have undergone such ecological regime shifts due to overfishing. The Black Sea has experienced a depletion in number of marine predator species and a concurrent increase in numbers of an alien comb jelly species, Mnemiopsis leidyi (Daskalov 
et al. 2007). The Nova Scotian shelf system was formerly dominated by Atlantic Cod, Gaddus morhua, with intense fishing pressure altering the system from one dominated by predators to a system dominated by forage species (Frank et al. 2005).

Another fishing practice with extensive ecological repercussions is "fishing down the food web," in which a fishery, upon effectively depleting a large apex predator (i.e. high trophic level species), subsequently targets the next largest species (i.e. likely a similar or next trophic level species), further altering ecological communities (Pauly et al. 1998). In what can be called tragic irony, the practice of fishing down the food web has the potential of masking or relaxing the effects of trophic cascades because it can involve targeting species of multiple trophic levels within the food web (Andersen and Pedersen 2009, Mumby et al. 2012). Christensen et al. (2014) showed evidence of this practice occurring on a global scale, as biomass of low trophic level prey fish species increased as biomass of high trophic level predatory fish declined. It therefore continues to be urgent and imperative for fisheries science and management to address and preempt the issues caused by widespread overfishing.

\subsection{Marine Protected Areas}

One possible method to alleviate the effects of overfishing is the establishment of marine protected areas (MPAs). Federal executive order \#13158 defines a U.S. marine protected area as "any area of the marine environment that has been reserved by Federal, State, territorial, tribal, or local laws or regulations 
to provide lasting protection for part or all of the natural and cultural resources therein." The National Oceanic and Atmospheric Administration's (NOAA) MPA Center further describes MPAs based on five objective characteristics (Wenzel and D'lorio 2011):

1. conservation focus (e.g., natural or cultural heritage, or resource sustainability)

2. level of protection (e.g., activities allowed, no-take, no-access)

3. permanence of protection (e.g., permanent, conditional, or temporary)

4. constancy of protection (e.g., year-round, seasonal, or rotating)

5. scale of protection (e.g., ecosystem or focused)

The biological and ecological benefits of marine protected areas have been extensively documented. In a meta-analysis encompassing 149 studies of 124 different no-take marine reserves around the world, higher biomasses, greater densities, higher species richness, and larger organism sizes were noted within reserves relative to nearby unprotected areas; these effects were observed regardless of reserve location, displaced fishing effort, latitude, or reserve size (Lester et al. 2009). Though it appears that beneficial impacts of marine protected areas on biomasses and densities are more pronounced for no-take marine reserves, even partial protection of an area has been found to be sufficient to result in higher biomasses and greater densities (Sciberras et al. 2013). 
In addition to benefitting organisms within the reserves themselves, marine protected areas can also benefit adjacent areas through the "spillover" effect, in which productivity and flourishing within a reserve causes adults to "spill over" into adjacent areas. This spillover of adults then benefits adjacent fisheries, especially those that practice "fishing the line," in which fishing vessels straddle the boundary of an MPA; fishing the line is capable of impacting spatial patterns of CPUE and density within and outside of a marine reserve, and even enhance total population size and catch for overexploited species under a limited set of conditions (Kellner et al. 2007). In a meta-analysis of studies until 2009 that contained empirical spillover data, it was found that at small scales (up to $800 \mathrm{~m}$ from reserve boundaries) a majority of the fisheries (12 of 14) likely depend upon the adjacent reserves for sustainability, and that in the other two cases spillover from the reserves partially or fully made up for decreases in catch from reserve closure (Halpern et al. 2009). Another meta-analysis found a gradual annual increase in CPUE from seven MPAs in Southern Europe, albeit on an extended time frame (at least 30 years) (Vandeperre et al. 2011).

Despite the widely-documented benefits of MPAs, there are still crucial information gaps in terms of the design of MPA studies. In their wide metaanalysis of 149 studies, Lester et al. (2009) found that studies that compared data from before an MPA's establishment to after its establishment were somewhat rare (some recent exceptions to this are Alemany et al.'s (2013) study on the MPA Southwest Atlantic Patagonian Shelf and Rife et al.'s (2013) study on the Loreto Bay National Park MPA in the Gulf of California). Another meta-analysis of 164 
studies of no-take marine reserves found that many studies did not adequately take habitat effects into account (Miller and Russ 2014).

Furthermore, few studies to date have explicitly assessed quantitative impacts of MPAs on reproductive output through time, particularly in terms of effects on numbers of fish larvae (but see Valles et al. 2001 and López-Sanz et al. 2009). There have been a few studies on eggs and larvae of conch species (Stoner and Ray 1997, Manriquez and Castilla 2001); other studies that showed reserve benefits for reproductive output were based on proxies such as adult organism size, fecundity, and biomass (Willis et al. 2003, Beukers-Stewart et al. 2005, Diaz et al. 2011). Enhancement of reproductive output is an important function of MPAs, as it holds implications for exporting larvae to adjacent areas (e.g. larval spillover) and thus amplifying production on a regional scale (Pelc et al. 2009).

\subsection{Rockfish Biology}

Rockfishes (Sebastes spp.) are a speciose group of demersal fishes found mostly along the west coast of North America (Hyde and Vetter 2007). Whereas some species are relatively small $(<20 \mathrm{~cm})$, short-lived $(<10$ years $)$ and provide an important forage base for predatory fishes and marine mammals, others grow to large sizes $(>90 \mathrm{~cm}$ ), live for many decades, and are apex predators (Love et al. 2002); individuals of some of these larger species, such as Rougheye Rockfish (S. aleutianus), have been estimated at ages up to 205 years (Love et al. 2002).

Rockfishes are viviparous (Boehlert and Yoklavich 1984), giving live birth to preflexion planktonic larvae (Love et al. 2002). Despite their viviparity, 
rockfishes appear to have fecundities comparable in magnitude to similarly-sized oviparous fishes, such as snappers (Lutjanidae) and cods (Gadidae) (Haldorson and Love 1991). Many rockfish species do not reach sexual maturity until they are four to five years old (Lea et al. 1999), and, consistent with the "big old fat fecund female fish" hypothesis (Longhurst 2002), there are significant correlations between adult female rockfish size and fecundity, larval survival, and ultimately recruitment (Haldorson and Love 1991, Berkeley et al. 2004, Sogard et al. 2008). In the Southern California Bight (SCB), rockfish parturition seasons for individual species range from two to ten months, with overall peak parturition activity during early winter (January-February) for most species (Love et al. 1990, Moser et al. 2001).

Rockfish larvae range from 3-7 mm in length upon release from the mother, and undergo a developmental transition around 8 to 25 days, depending on the species, known as "flexion." During flexion, the posterior end of the notochord turns upward and fins begin to differentiate; larvae range from 6-12 $\mathrm{mm}$ by the time they reach flexion (Love et al. 2002). Rockfish larvae are usually found over the continental shelf and slope at depths of less than $80 \mathrm{~m}$, typically within the upper mixed layer and the thermocline (Love et al. 2002), though Hitchman et al.'s (2012) more recent work found that the negative relationship of $S$.

paucispinis larvae with depth is significant only for recently hatched larvae with older preflexion and postflexion larvae having no significant relationship to depth. 


\subsection{The Rockfish Fishery in the Southern California Bight (SCB)}

Many rockfish species have been targeted by recreational and commercial fisheries, which has led to severe population declines. Commercial and recreational fishing of Sebastes spp. along the Pacific coast began in the late nineteenth century, but exploitation was significantly accelerated by sociological factors and technological advances in the twentieth century [e.g. use of balloon trawls, roller gear, loran plotters, and midwater trawls, greater understanding of productive rockfish habitats, and an influx of immigrants that contributed to the fishing effort (Love et al. 2002)]. A survey of commercial passenger fishing vessels in the SCB region from 1980 to 1996 revealed drastic declines in CPUE and mean total length of multiple rockfish species, such as Bocaccio $(S$. paucispinis), and the Blue (S. mystinus), Olive (S. serranoides), Chilipepper (S. goodei), Swordspine (S. ensifer), Yellowtail (S. flavidus), and Vermilion (S. miniatus) rockfishes (Love et al. 1998). Moser et al. (2000) also observed declines in larval abundances and adult biomasses of S. paucispinis and S. levis in fishery-independent surveys from 1977-1998. Moser et al. (2000) suggested environmental conditions (i.e., a shift to a warm climate regime at that time) and fishery exploitation as possible explanatory factors for the declines; however, a later study determined that the regime shift did not significantly impact $S$. paucispinis productivity, supporting the idea that the declines were more likely due to fishery exploitation (Tolimieri and Levin 2005). In their assessment of several nearshore rockfish species spanning from 1979 to 1985, Lea et al. (1999) found that juveniles often comprised a large percentage of the sport take. 
Taken all together, these observations indicate that the rockfish fishery had depleted older, larger, and more fecund adults and is very likely removing juveniles from the populations as well, thereby impacting population sizes and age structures of targeted rockfishes. For example, a study on fishing effort of commercial passenger fishing vessels showed that catches in the 1980s were mostly made up of large species such as S. paucispinis and S. levis while the smaller S. hopkinsi was the most frequently caught species in 1996 (Love et al. 1998). Fishery-independent surveys of larval rockfishes in the SCB region in 1999 (Taylor et al. 2004) and 2005 (Thompson et al. 2016) were also dominated by larvae from smaller, non-targeted species (i.e., Swordspine, S. ensifer, and Shortbelly, S. jordani) in addition to S. hopkinsi. Hsieh et al. (2005) found that larval abundances of $S$. paucispinis declined relative to $S$. jordani between 1951 and 2002.

Rockfishes are also vulnerable to fishing because of their high capture-related mortality due to barotrauma, in which rapid gas expansion in the swim bladder causes the fish's stomach to bulge out of its mouth and prevents them from submerging (O'Connell and Carlile 1994, Butler et al. 2003). This high surface mortality could result in relatively high bycatch in local fisheries that do not target rockfishes, such as the flatfish fishery on the western U.S. coast (King et al. 2004, Hannah et al. 2005) and the spot prawn fishery in British Columbia (Favaro et al. 2010, 2013). Recent research, however, shows that rockfish can survive barotrauma if they are slowly lowered to depth (Chen 2012). 
Rockfishes may not be the only group affected by the rockfish fishery, as fishing of rockfish species could also have negative ecological repercussions via triggering of trophic cascades. A meta-analysis of various ecosystems found marine benthic ecosystems to be particularly sensitive to trophic cascades (Shurin et al. 2002). It has also been suggested that declines in abundances of large predatory groundfishes may have resulted in a trophic cascade off of Nova Scotia (Frank et al. 2005, 2011). In his study of Sebastes spp. off the coast of British Columbia, Cloutier (2011) did not observe evidence of a trophic cascade; however, Cloutier proposed several explanations for why a cascade was not observed, such as rockfish populations being below critical abundance and/or size thresholds to trigger a cascade, or not enough time elapsing between rockfish population recovery and initiation of a cascade.

\subsection{Southern California Bight Oceanography}

In addition to being subject to fishing pressure, rockfish species in the SCB are also affected by the region's dynamic oceanographic conditions. There are four primary water masses that comprise the California Current System, each with their own unique characteristics in terms of temperature, salinity, oxygen content, and nutrient concentrations (McClatchie 2014):

1) the cool, fresh, oxygen-rich, and nutrient-rich Pacific Subarctic mass, which is transported southward by the California Current (CC); 
2) the warm, saline Equatorial Pacific mass, which is transported northward at depths between 200 and $500 \mathrm{~m}$ by the California Undercurrent;

3) the warm, saline, oxygen-poor, and nutrient-poor North Pacific Central mass, originating from the North Pacific Gyre;

4) the cool, saline, oxygen-poor, and nutrient-rich Coastal Upwelled mass, originating from wind-driven upwelling of deeper waters near the coast.

The convergence in the SCB of these water masses, as well as the processes that transport these masses, have important implications for rockfish productivity, distribution, retention, and early life history dynamics.

Convergence of the water masses in the SCB results in frontal featuresinterfaces between two water masses with distinctly different physical characteristics - such as the semi-permanent frontal region between the Santa Rosa and Santa Cruz ridges (McClatchie 2014). Fronts have been shown to be regions of high abundance and diversity for organisms across different trophic levels (Woodson et al. 2012). Rockfish recruitment was shown to be positively correlated with probability of frontal features in the northern and central portions of the California Current System (Woodson et al. 2012), and fronts also appear to influence distribution of pelagic juvenile rockfish (Sakuma et al. 2013).

The convergence of processes that transport the major water masses, i.e. the currents and winds, result in the SCB being an area of dynamic circulation. The governing currents are the southward-flowing California Current and the northward-flowing Southern California Countercurrent, which are responsible for 
transporting the Pacific Subarctic mass southward and warmer, inshore water northward, respectively. The Southern California Countercurrent (SCC) forms when the CC collides with warm, southern waters at around $32{ }^{\circ} \mathrm{N}$ (approximately off the coast of Ensenada, Mexico). Here, the CC current bifurcates with part of the CC turning east, becoming warmer, and then flowing north along the coast, becoming the SCC. Upon reaching the Channel Islands, the SCC again bifurcates with part of it flowing west along the south side of the Channel Islands and then rejoining the main branch of the $\mathrm{CC}$, while the other part continues north into the Santa Barbara Channel. This cyclonic flow within the SCB is known as the Southern California Eddy (SCE) (Fig 1.1) (Lynn and Simpson 1987). Although the anti-cyclonic flow in the SCB is evident most of the year, its strength fluctuates seasonally, increasing in strength during spring and especially during summer (Hickey 1979, Lynn and Simpson 1987, DiLorenzo 2003). The SCE has been shown to enhance retention of S. hopkinsi and S. ensifer larvae in the SCB (Taylor et al. 2004). Within the SCB, the south-flowing CC tends to move along the Santa Rosa ridge that runs between the Santa Rosa and San Nicholas Islands, while the SCC flows along the Santa Cruz ridge that connects Santa Cruz and Catalina Islands (McClatchie 2014).

Upwelling-favorable winds are present to various degrees throughout the year in the SCB (Ibid.). This is important because upwelling appears to notably influence the early life history dynamics of rockfishes. The Bakun upwelling index is strongly and positively correlated with interannual variation in settlement of multiple rockfish species off the Channel Islands (Caselle et al. 2010). In a 
data-assimilative regional oceanic modeling system (ROMS) reanalysis, regional upwelling characteristics in the late winter months were found to be positively correlated with abundances of juvenile rockfishes in spring (Schroeder et al. 2014). Lastly, regional productivity was found to positively influence settlement, juvenile recruitment, and individual growth of rockfishes, suggesting that largescale oceanographic processes that stimulate upwelling are important for larval growth and subsequent year-class strength in rockfishes (Wheeler et al. 2016).

Further variability in the SCB is introduced via large-scale climatic oscillations (e.g., El Niño-Southern Oscillation), which influence circulatory patterns as well as oceanographic parameters such as chlorophyll a and sea surface temperature (Bograd and Lynn 2003). A model assessed that variance in S. paucispinis recruitment appears to be influenced by an interaction between population density and positive Northern Oscillation Index values, which is associated with stronger trade winds and coastal upwelling, as well as cooler upper ocean temperatures and increased macrozooplankton volume off the coast of southern California (Zabel et al. 2011). However, a study of pelagic juvenile rockfish abundances from midwater trawl surveys found poor correlation between abundances and basin-scale indices (i.e. El Niño-Southern Oscillation, Pacific Decadal Oscillation, North Pacific Gyre Oscillation, and Northern Oscillation) (Ralston et al. 2013).

Another distinctive characteristic of the SCB is low dissolved oxygen concentrations, particularly in deeper waters and basins (McClatchie et al. 2010). Hypoxic conditions $(<1.5 \mathrm{~mL} \cdot \mathrm{L}-1)$ result in some aerobic organisms 
experiencing respiratory stress, restricting their activity and distribution to areas with sufficient oxygen levels (Deutsch et al. 2011). Because deeper waters are more likely to be hypoxic, demersal species, such as rockfishes, may be especially impacted by hypoxia; there has been concern that observed shoaling of oxygenminimum waters in the SCB will negatively impact rockfishes by significantly reducing the amount of suitable habitat (McClatchie et al. 2010). However, in a study of Quillback (S. maliger) and Copper (S. caurinus) rockfish responses to hypoxic conditions, the authors proposed that other characteristics of the hypoxic water mass such as origin, chemistry, and temperature, must also be considered in addition to oxygen levels in order to fully comprehend the effects of hypoxia on rockfishes and other fishes (Rankin et al. 2013).

\subsection{Cowcod Conservation Areas and Rockfish Conservation Areas}

In 2001, in response to the drastic decline in populations of commercial rockfishes, especially cowcod (S. levis), which was declared overfished in 1999 (Butler et al. 1999), the Pacific Fishery Management Council and the California Department of Fish and Game established the Cowcod Conservation Areas (CCAs). The CCAs comprise two areas in the SCB region where bottom-fishing deeper than $36 \mathrm{~m}$ is prohibited — a larger western area encompassing roughly $10,878 \mathrm{~km}^{2}$, and a smaller area to the east encompassing roughly $260 \mathrm{~km}^{2}$ (Fig 1.2). In the following year, Rockfish Conservation Areas (RCAs) were established along the entire western North American coast from California to British Columbia (Yamanaka and Logan 2008). 
A handful of studies have been conducted that suggest that the CCAs' potentially benefit targeted rockfishes. Based on larval abundances in the SCB derived and calculated from mesozooplankton samples collected in 2004, Hitchman et al. (2012) found the CCAs to be an ideal parturition habitat for $S$. paucispinis. Based on similarly-derived larval abundances in the SCB for 2005, Thompson et al. (2016) found higher rockfish species richness and targeted rockfish abundance within the CCAs. A 2012 ROV survey of the CCAs found that encounter rates with S. levis were higher within the CCAs than outside of them (Stierhoff et al. 2013).

Research has also been conducted assessing the efficacy of RCAs north of the SCB. Bottom trawl surveys conducted in the U.S. RCAs between 2003 and 2011 found significant increases in demersal species abundance, indicating that the U.S. RCAs may be facilitating the recovery of rockfish populations (Keller et al. 2014). However, the Canadian RCAs may not be performing as effectively, as there have been mixed results among various studies conducted within the past decade. The most recent studies by Haggarty $(2015,2016)$ seem to indicate that the RCAs around Vancouver Island are not facilitating recovery of demersal fish populations.

Despite the CCAs' 15 years of establishment, no comprehensive systematic study of the reserve on targeted rockfish populations had been conducted until now. The lack of time-series data has been noted by stock assessments (Dick and MacCall 2014, He et al. 2015) and ecological studies (Yoklavich et al. 2007, Thompson et al. 2012) conducted in the region, and is important to our 
understanding of the efficacy of the CCAs in their ability to facilitate recovery of overfished rockfish species.

\subsection{Questions and Hypotheses}

This study aimed to fill in crucial information gaps in the understanding of MPAs' impacts on reproductive output as well as provide a clearer picture of the CCAs' impacts on targeted rockfishes in the SCB; this was accomplished through construction and analysis of a 16-year time series spanning from 1998 to 2013 from four years before the establishment of the CCA to 12 years afterward. and addressing the following research questions:

1. How have abundances of larvae of targeted rockfishes in the SCB changed during the study period?

$\mathrm{H}_{0}$ : There will be no significant relationship between abundances of larvae of targeted rockfishes and time.

2. How do the presence of larvae of targeted rockfish species relate to temperature, salinity, chlorophyll a, and oxygen?

$\mathrm{H}_{0}$ : There is no significant relationship between presence of larvae of targeted rockfish species and temperature, salinity, chlorophyll a, nor oxygen.

3. How do temporal trends in abundances of targeted rockfish larvae within the CCAs compare to temporal trends in abundances of targeted rockfish larvae outside of the CCAs? 
$\mathrm{H}_{0}$ : There is no significant difference in temporal trends in abundances of targeted rockfish larvae within the CCAs compared to temporal trends in abundances of targeted rockfish larvae outside of the CCAs. 
Figure 1.1 Map of the SCB showing some of the current dynamics of the region, including the CC, SCC, and SCE taken from Hickey (1992). 
Circulation Patterns in the Southern California Bight

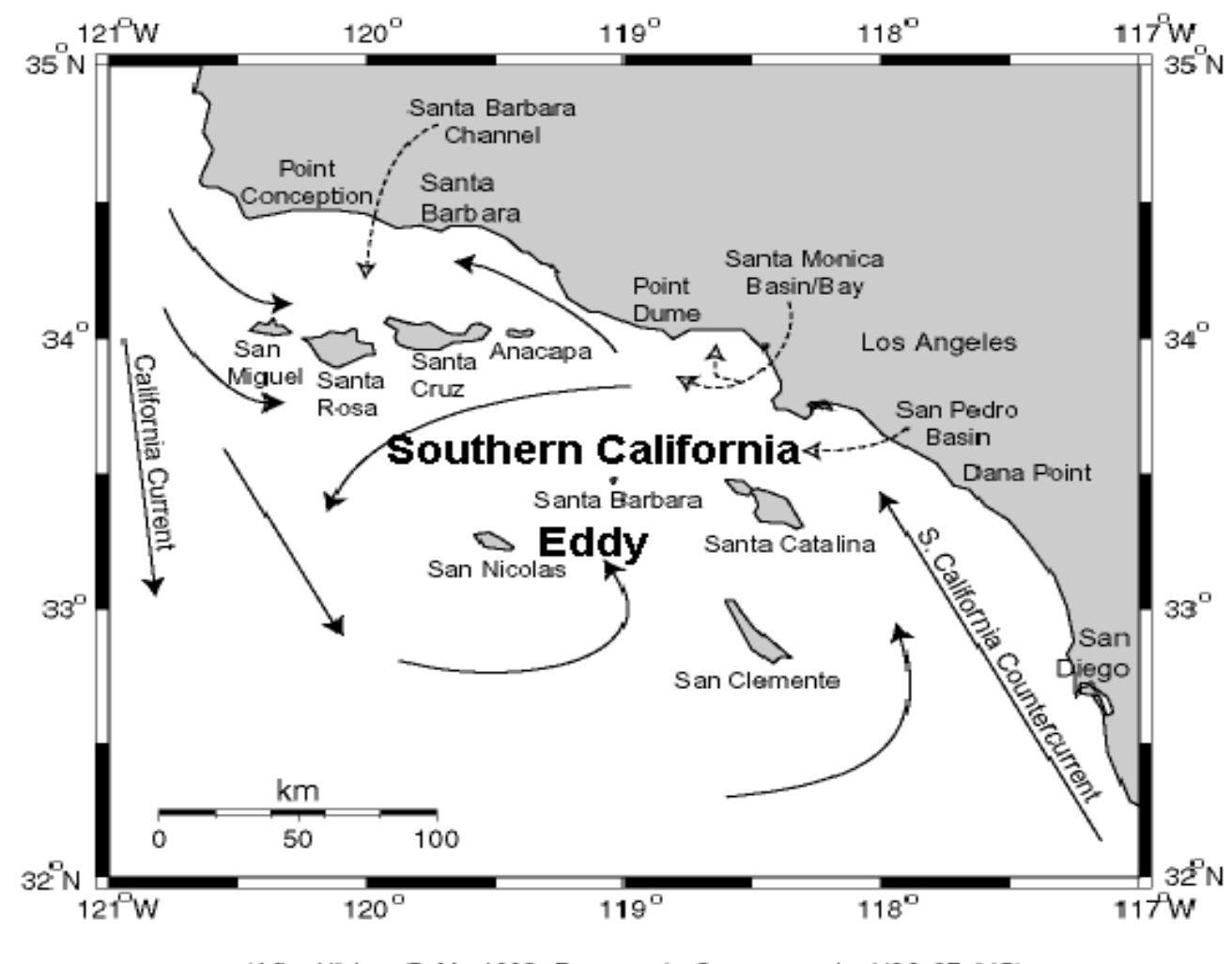

(After Hickey, B. M., 1992, Progress in Oceanography, V30: 37-115) 
Figure 1.2 Map of CalCOFI stations used in this study and the boundaries of the Cowcod Conservation Areas off of southern California, USA. Numbers represent the CalCOFI line and station of each sample location. 


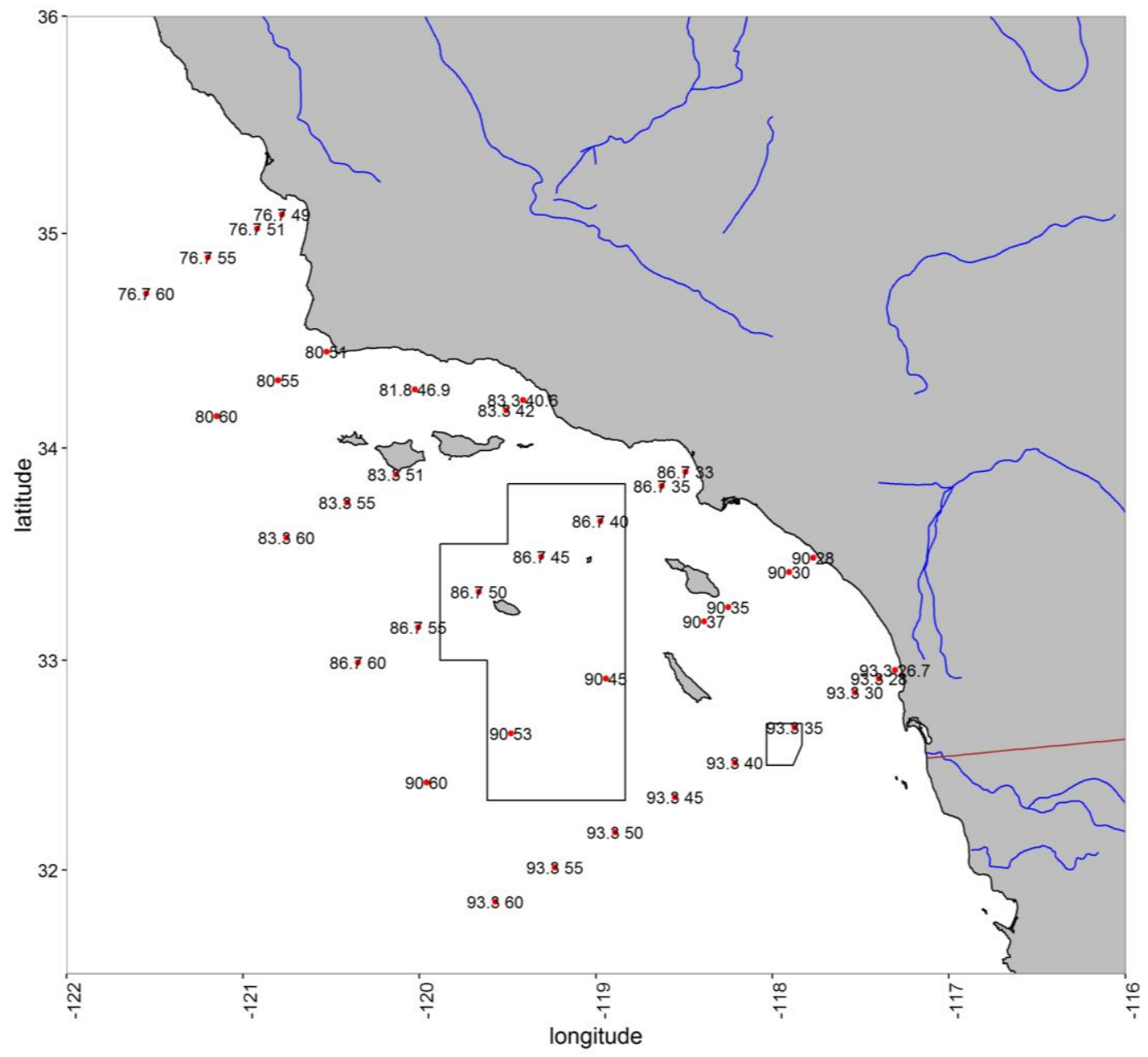




\section{References}

1. ALEMANY, D., Iribarne, O.O., and E.M. Acha. 2013. Effects of a large-scale and offshore marine protected area on the demersal fish assemblage in the Southwest Atlantic. ICES Journal of Marine Science 70:123-134.

2. ANDERSEN, K.H., and M. Pedersen. 2009. Damped trophic cascades driven by fishing in model marine ecosystems. Proceedings of the Royal Society of London B: Biological Sciences, rspb20091512.

3. BERKELEY, S.A., C. Chapman, and S.M. Sogard. 2004. Maternal age as a determinant of larval growth and survival in a marine fish, Sebastes melanops. Ecology 85(5): 1258-1264.

4. BEUKERS-STEWART, B.D., Vause, B.J., Mosely, M., Rossetti, H.L., and A.R. Brand. 2005. Benefits of closed area protection for a population of scallops. Marine Ecology Progress Series 298:189-204.

5. BOEHLERT, G.W. and M.M. Yoklavich. 1984. Reproduction, embryonic energetics, and the maternal-fetal relationship in the viviparous genus Sebastes (Pisces: Scorpaenidae). Biology Bulletin 167: 354-370.

6. BOGRAD, S.J. and R.J. Lynn 2003. Long-term variability in the Southern California Current System. Deep Sea Research Part II: Topical Studies in Oceanography 50(14-16): 2355-2370.

7. BUTLER, J.L., L.D. Jacobson, J.T. Barnes, H.G. Moser, and R. Collins. 1999. Stock assessment of cowcod. Pacific Fishery Management Council. Web. 26 Apr 2014. < http:// www.pcouncil.org/wpcontent/uploads/Cowcod_1999_Assessment.pdf> 
8. BUTLER, J.L., L.D. Jacobson, J.T. Barnes, and H.G. Moser. 2003. Biology and population dynamics of cowcod (Sebastes levis) in the Southern California Bight. Fishery Bulletin 101(2): 260-280.

9. California Cowcod Conservation Areas. California Department of Fish and Wildlife. Web. 19 Dec 2013.

10. CASELLE, J.E., M.H. Carr, D.P. Malone, J.R. Wilson, D.E. Wendt. 2010. Can we predict interannual and regional variation in delivery of pelagic juveniles to nearshore populations of rockfishes (genus Sebastes) using simple proxies of ocean conditions? CalCOFI Report 51: 91-105.

11. CHEN, I. 2012. Putting rockfish back where they belong. Science 338(6107):600-601.

12. CHRISTENSEN, V., Coll, M., Piroddi, C., Steenbeek, J., Buszowski, J., and D. Pauly. 2014. A century of fish biomass decline in the ocean. Mar. Ecol. Prog. Ser. 512:155-166.

13. CLOUTIER, R.N. Direct and indirect effects of marine protection: rockfish conservation areas as a case study. M. Sc. thesis. Simon Fraser University, 2011.

14. DASKALOV, G.M., Grishin, A.N., Rodionov, S., and V. Mihneva. 2007. Trophic cascades triggered by overfishing reveal possible mechanisms of ecosystem regime shifts. Proceedings of the National Academy of Sciences 104(25):10518-10523.

15. DEUTSCH, C., H. Brix, T. Ito, H. Frenzel, and L. Thompson. 2011. ClimateForced Variability of Ocean Hypoxia. Science 333: 336-339. 
16. DÍAZ, D., Mallol, S., Parma, A.M., and R. Goñi. 2011. Decadal trend in lobster reproductive output from a temperate marine protected area. Marine Ecology Progress Series 433:149-157.

17. DICK, E.J. and A.D. MacCall. 2014. Status and productivity of cowcod, Sebastes levis, in the Southern California Bight, 2013. Pacific Fishery Management Council, Portland, OR.

18. DILORENZO, E. 2003. Seasonal dynamics of the surface circulation in the Southern California Current System. Deep Sea Research Part II: Topical Studies in Oceanography, 50(14-16): 2371-2388.

19. Executive Order No. 13158, 3 C.F.R. 34909 (2000). Print.

20. FAVARO, B., Rutherford, D.T., Duff, S.D., Coté, I.M. 2010. Bycatch of rockfish and other species in British Columbia spot prawn trap: Preliminary assessment using research traps. Fisheries Research 102(1):199-206.

21. FAVARO, B., Duff, S.D., Coté, I.M. 2013. A trap with a twist: evaluating a bycatch reduction device to prevent rockfish capture in crustacean traps. ICES Journal of Marine Science: Journal of Marine Science: Journal du Conseil 70(1):114-122.

22. FRANK, K.T., B. Petrie, J.S. Choi, and W.C. Leggett. 2005. Trophic cascades in a formerly cod-dominated ecosystem. Science 308: 1621-1623.

23. HAGGARTY, D.R. 2015. An evaluation of the effectiveness of Rockfish Conservation Areas in British Columbia, Canada. Ph.D. dissertation. University of British Columbia. 
24. HAGGARTY, D.R. 2016. Assessing population recovery inside British Columbia's Rockfish Conservation Areas with a remotely operated vehicle. Ph.D. dissertation. University of British Columbia.

25. HALDORSON, L. and M. Love. 1991. Maturity and Fecundity in the Rockfishes, Sebastes spp., a Review. Marine Fisheries Review 53(2): 25-31.

26. HALPERN, B.S., Lester, S.E., and J.B. Kellner. 2009. Spillover from marine reserves and the replenishment of fished stocks. Environmental Conservation 36(4):268-276.

27. HANNAH, R.W., S.J. Parker, and T.V. Buell. 2005. Evaluation of a selective flatfish trawl and diel variation in rockfish catchability as bycatch reduction tools in the deepwater complex fishery off the U.S. West Coast. North American Journal of Fisheries Management 25: 581-593.

28. HE, X., Field, J.C., Pearson, D.E., Lefebvre, L., and S. Lindley. 2015. Status of Bocaccio, Sebastes paucispinis, in the Conception, Monterey and Eureka INPFC areas for 2015. Pacific Fishery Management Council, Portland, Or.

29. HICKEY, B.M. 1979. The California current system-hypotheses and facts. Progress in Oceanography 8(4): 191-279.

30. HICKEY, B.M. 1992. Circulation over the Santa Monica-San Pedro Basin and Shelf. Progress in Oceanography 30(1-4): 37-115.

31. HITCHMAN, S.M., N.B. Reyns, and A.R. Thompson. 2012. Larvae define spawning habitat of bocaccio rockfish Sebastes paucispinis within and around a large southern California marine reserve. Marine Ecology Progress Series 465: $227-242$. 
32. HSIEH, C., C.S. Reiss, W. Watson, M.J. Allen, J.R. Hunter, R.N. Lea, R.M. May, and G. Sugihara. 2005. A comparison of long-term trends and variability in populations of larvae of exploited and unexploited fishes in the Southern California region: A community approach. Progress in Oceanography 67: 160185.

33. HYDE, J.R. and R.D. Vetter. 2007. The origin, evolution, and diversification of rockfishes of the genus Sebastes (Cuvier). Molecular Phylogenetics and Evolution 44: 790-811.

34. JACKSON, J.B.C., M.X. Kirby, W.H. Berger, K.A. Bjorndal, L.W. Botsford, B.J. Bourque, R.H. Bradbury, R. Cooke, J. Erlandson, J.A. Estes, T.P. Hughes, S. Kidwell, C.B. Lange, H.S. Lenihan, J.M. Pandolfi, C.H. Peterson, R.S. Steneck, M.J. Tegner, and R.R. Warner. 2001. Historical Overfishing and the Recent Collapse of Coastal Ecosystems. Science 293: 629-638.

35. KELLER, A.A., Wakefield, W.W., Whitmire, C.E., Horness, B.H., Bellman, M.A., and K.L. Bosley. 2014. Distribution of demersal fishes along the US west coast (Canada to Mexico) in relation to spatial fishing closures (20032011). Marine Ecology Progress Series 501:169-190.

36. KELLNER, J.B., Tetreault, I., Gaines, S.D., and R.M. Nisbet. 2007. Fishing the line near marine reserves in single and multispecies fisheries. Ecological Applications 17(4):1039-1054.

37. KING, S.E., R.W. Hanna, S.J. Parker, K.M. Matteson, and S.A. Berkeley. 2004. Protecting rockfish through gear design: development of a selective 
flatfish trawl for the U.S. west coast bottom trawl fishery. Canadian Journal of Fisheries and Aquatic Sciences 61(3): 487-496.

38. LEA, R.N., R.D. McAllister, and D.A. VenTresca. 1999. Biological aspects of nearshore rockfishes of the genus Sebastes from central California with notes on ecologically related sport fishes. Fishery Bulletin 177: 1-112.

39. LESTER, S.E., B.S. Halpern, K. Grorud-Colvert, J. Lubchenco, B.I. Ruttenberg, S.D. Gaines, S. Airamé, and R.R. Warner. 2009. Biological effects within no-take marine reserves: a global synthesis. 2009. Marine Ecology Progress Series 384: 33-46.

40. LONGHURST, A. 2002. Murphy's law revisited: longevity as a factor in recruitment to fish populations. Fisheries Research 56(2): 125-131.

41. LÓPEZ-SANZ, À., Vert, N., Zabala, M., and A. Sabatés. 2009. Small-scale distribution of fish larvae around the Medes Islands marine protected area (NW Mediterranean). Journal of Plankton Research fbp024.

42. LOVE, M.S., P. Morris, M. McCrae, and R. Collins. 1990. Life history aspects of 19 rockfish species (Scorpaenidae: Sebastes) from the Southern California Bight. NOAA Technical Report NMFS 87. 38 pp.

43. LOVE, M.S., J.E. Caselle, and W.V. Buskirk. 1998. A severe decline in the commercial passenger fishing vessel rockfish (Sebastes spp.) catch in the Southern California Bight, 1980-1996. CalCOFI Report 39: 180-195.

44. LOVE, M.S., M.M. Yoklavich, and L. Thorsteinson. 2002. The Rockfishes of the Northeast Pacific. University of California Press, Berkeley and Los Angeles, 404 pp. 
45. LYNN, R.J., and J.J. Simpson. 1987. The California Current system: the seasonal variability of its physical characteristics. Journal of Geophysical Research 92: 12947-12966.

46. MANRIQUEZ, P.H. and J.C. Castilla. 2001. Significance of marine protected areas in central Chile as seeding grounds for the gastropod Concholepas concholepas. Marine Ecology Progress Series 215:201-211.

47. MCCLATCHIE, S., R. Goericke, R. Cosgrove, G. Auad, and R. Vetter. 2010. Oxygen in the Southern California Bight: Multidecadal trends and implications for demersal fisheries, Geophysical Research Letters 37 L19602, doi:10.1029/2010GL044497.

48. MCCLATCHIE, S. 2014. Regional Fisheries Oceanography of the California Current System. Springer, New York, 235 pp.

49. MILLER, K.I. and G.R. Russ. 2014. Studies of no-take marine reserves: Methods for differentiating reserve and habitat effects. Ocean \& Coastal Management 96:51-60.

50. MOSER, H.G., R.L. Charter, W. Watson, D.A. Ambrose, J.L. Butler, S.R. Charter, and E.M. Sandknop. 2000. Abundance and distribution of rockfish (Sebastes) larvae in the Southern California Bight in relation to environmental conditions and fishery exploitation. CalCOFI Report 41:32-47.

51. MOSER, H.G., R.L. Charter, W. Watson, D.A. Ambrose, K.T. Hill, P.E. Smith, J.L. Butler, E.M. Sandknop, and S.R. Charter. 2001. The CalCOFI 
ichthyoplankton time series: potential contriutions to the management of rocky-shore fishes. CalCOFI Report 42: 112-128.

52. MUMBY, P.J., Steneck, R.S., Edwards, A.J., Ferrari, R., Coleman, R., Harborne, A.R., Gibson, J.P. 2012. Fishing down a Caribbean food web relaxes trophic cascades. Mar. Ecol. Prog. Ser. 445:13-24.

53. MYERS, R.A. and B. Worm. 2003. Rapid worldwide depletion of predatory fish communities. Nature 423: 280-283.

54. O'CONNELL, V.M. and D.W. Carlile. 1994. Comparison of a remotely operated vehicle and a submersible for estimating abundance of demersal shelf rockfishes in the eastern Gulf of Alaska. North American Journal of Fisheries Management 14: 196-201.

55. PAULY, D., V. Christensen, J. Dalsgaard, R. Froese, and F. Torres, Jr. 1998. Fishing Down Marine Food Webs. Science 279(5352): 860-863.

56. PELC, R.A., Warner, R.R., Gaines, S.D., and C.B. Paris. 2009. Detecting larval export from marine reserves. PNAS 107(43):18266-18271.

57. PITCHER, T.J. and W.W.L. Cheung. 2013. Fisheries: Hope or despair? Marine Pollution Bulletin 74(2):506-516.

58. RALSTON, S., Sakuma, K.M., and J.C. Field. 2013. Interannual variation in pelagic juvenile rockfish (Sebastes spp.) abundance—-going with the flow. Fisheries Oceanography 22(4):288-308.

59. RANKIN, P.S., Hannah, R.W., and M.T.O. Blume. 2013. Effect of hypoxia on rockfish movements: implications for understanding the roles of temperature, toxins and site fidelity. Mar. Ecol. Prog. Ser. 492:223-234. 
60. RIFE, A.N., Aburto-Oropeza, O., Hastings, P.A., Erisman, B., Ballantyne, F., Wielgus, J., Sala, E., and L. Gerber. 2013. Long-term effectiveness of a multiuse marine protected area on reef fish assemblages and fisheries landings. Journal of Environmental Management 117:276-283.

61. SAKUMA, K.M., Bjorkstedt, E.P., and S. Ralston. 2013. Distribution of Pelagic Juvenile Rockfish (Sebastes spp.) in Relation to Temperature and Fronts Off Central California. CalCOFI Rep 54:167-179.

62. SCHROEDER, I.D., Santora, J.A., Moore, A.M., Edwards, C.A., Fiechter, J., Hazen, E.L., Bograd, S.J., Field, J.C., and B.K. Wells. 2014. Application of a data-assimilative regional ocean modeling system for assessing California Current System ocean conditions, krill, and juvenile rockfish interannaul variability. Geophysical Research Letters 41(16):5942-5950.

63. SCIBERRAS, M., Jenkins, S.R., Kaiser, M.J., Hawkins, S.J., and A.S. Pullin. 2013. Evaluating the biological effectiveness of fully and partially protected marine areas. Environmental Evidence 2(1): 4.

64. SHURIN, J.B., E.T. Borer, E.W. Seabloom, K. Anderson, C.A. Blanchette, B. Broitman, S.D. Cooper, and B.S. Halpern. 2002. A cross-ecosystem comparison of the strength of trophic cascades. Ecology Letters 5: 785-791.

65. SOGARD, S.M., S.A. Berkeley, and R. Fisher. 2008. Maternal effects in rockfishes Sebastes spp.: a comparison among species. Marine Ecology Progress Series 360: 227-236.

66. STIERHOFF, K.L., Mau, S.A., and D.W. Murfin. 2013. A fisheryindependent survey of cowcod (Sebastes levis) in the Southern CA Bight 
using a remotely operated vehicle (ROV). NOAA Technical Memorandum NOAA-TM-NMFS-SWFSC-520.

67. STONER, A.W. and M. Ray. 1997. Queen conch, Strombus gigas, in fished and unfished locations of the Bahamas: effects of a marine fishery reserve on adults, juveniles, and larval production. Oceanographic Literature Review 5(44):515-516.

68. TAYLOR, C.A., W. Watson, T. Chereskin, J. Hyde, and Vetter, R. 2004. Retention of larval rockfishes, Sebastes, near natal habitat in the Southern California Bight, as indicated by molecular identification methods. CalCOFI Report 45: 152-166.

69. THOMPSON, A.R., W.W. Watson, S. McClatchie, and E.D. Weber. 2012. Multi-scale sampling to evaluate assemblage dynamics in an oceanic marine reserve. PloS ONE 7:e33131.

70. THOMPSON, A.R., Hyde, J.R., Watson, W., Chen, D.C., and L.W. Guo. 2016. Rockfish assemblage structure and spawning locations in southern California identified through larval sampling. Mar Ecol Prog Ser 547:177192.

71. TOLIMIERI, N. and P.S. Levin. 2005. The roles of fishing and climate in the population dynamics of bocaccio rockfish. Ecological Applications 15(2): $458-468$. 
72. VALLES, H., Sponaugle, S., and H.A. Oxenford. 2001. Larval supply to a marine reserve and adjacent fished area in the Soufriere Marine Management Area, St Lucia, West Indies. Journal of Fish Biology 59(sA):152-177.

73. VANDEPERRE, F., Higgins, R.M., Sánchez-Meca, J., Maynou, F., Goñi, R., Martín-Sosa, P., Pérez-Ruzafa, A., Afonso, P., Bertocci, I., Crec'hriou, R., D’anna, G., Dimech, M., Dorta, C., Esparza, O., Falcón, J.M., Forcada, A., Guala, I., Le Direach, L., Marcos, C., Ojeda-Martínez, C., Pipitone, C., Schembri, P.J., Stelzenmüller, V., Stobart, B., Santos, R.S. 2011. Effects of no-take area size and age of marine protected areas on fisheries yields: a metaanalytical approach. Fish and Fisheries 12(4): 412-426.

74. WENZEL, L. and M. D’lorio. 2011. Definition \& Classification System for U.S. Marine Protected Areas. National Marine Protected Areas Center. Web. 20 Dec 2013.

75. WHEELER, S.G., Anderson, T.W., Bell, T.W., Morgan, S.G., and J.A. Hobbs. 2016. Regional productivity predicts individual growth and recruitment of rockfishes in a northern California upwelling system. Limnology and Oceanography doi:10.1002/lno.10458

76. WILLIS, T.J., Millar, R.B., and R.C. Babcock. 2003. Protection of exploited fish in temperature regions: high density and biomass of snapper Pagrus auratus (Sparidae) in northern New Zealand marine reserves. Journal of Applied Ecology 40(2):214-227. 
77. WOODSON, C.B., M.A. McManus, J.A. Tyburczy, J.A. Barth, L. Washburn, J.E. Caselle, M.H. Carr, D.P. Malone, P.T. Raimondi, B.A. Menge, and S.R. Palumbi. 2012. Coastal fronts set recruitment and connectivity patterns across multiple taxa. Limnology and Oceanography 57(2): 582-596.

78. YAMANAKA, K.L., and G. Logan. 2008. Developing British Columbia’s inshore rockfish conservation strategy. Marine and Coastal Fisheries 2(1):2846.

79. YOKLAVICH, M.M., M.S. Love, and K.A. Forney. 2007. A fisheryindependent assessment of an overfished rockfish stock, cowcod (Sebastes levis), using direct observations from an occupied submersible. Canadian Journal of Fisheries and Aquatic Sciences 64(12): 1795-1804.

80. ZABEL, R.W., P.S. Levin, N. Tolimieri, and N.J. Mantua. 2011. Interactions between climate and population density in the episodic recruitment of bocaccio, Sebastes paucispinis, a Pacific rockfish. Fisheries Oceanography 20(4): 294-304. 


\section{CHAPTER 2: Evidence of increased larval production from a southern California marine protected area}

\subsection{Abstract}

Overfishing is affecting ecosystems and economies worldwide. Marine protected areas (MPAs) can facilitate recovery of diminished stocks. To notably augment fisheries, however, reproductive output must increase within the bounds of MPAs so that larvae can be exported to surrounding areas and seed the region. We evaluated dynamics of larval abundances of 8 rockfish species (Sebastes spp.) that were historically heavily fished and 7 that have not been directly targeted by fishing. Comparisons of abundances were made for 12 stations, sampled annually between 1998-2013, 6 inside and 6 outside of two large MPAs (Cowcod Conservation Areas (CCAs), established in 2001) off Southern California, USA. Mean abundances of 6/8 targeted and 3/7 non-targeted species increased during the study period at a regional scale. These increases were likely affected by environmental conditions in addition to changes in fishing pressure as the presence of most species correlated negatively with temperature, and temperature was lower than the historic average in 11/15 years. In addition, $75 \%$ of the targeted, but none of the non-targeted, species increased at a greater rate inside than outside the CCAs while controlling for environmental factors. This is one of the first quantitative demonstrations that MPAs can influence fish reproductive output. Results indicate that management actions, coupled with favorable environmental conditions, facilitated the resurgence of multiple rockfish species that were targeted by intense fishing effort for decades. 


\subsection{Introduction}

The negative impacts of fishing on targeted fish populations and fished ecosystems have been known for decades (Jackson et al. 2001, Myers and Worm 2003). The problem continues to this day, as significant depletions and declining catch-per-unit-effort (CPUE) were found to be a recurring trend world-wide (Pitcher and Cheung 2013). Further, predatory fish biomass is estimated to have declined by $2 / 3$ globally from 1880 to 2007 , and the rate of decline is still accelerating (Christensen et al. 2014). Additionally, overfishing has been shown to result in far-reaching ecological effects beyond simple population depletion, such as altering predation risk (Madin et al. 2016). Determining how to alleviate overfishing, therefore, is one of the most important issues for both fisheries science and management.

Marine protected areas (MPAs) or marine reserves hold the potential to assuage the effects of overfishing, especially for relatively sedentary species, and have been implemented globally over the past two decades (Lester et al. 2009). Meta-analyses consistently provide extensive evidence of both fisheries (Roberts et al. 2001, Halpern et al. 2009, Vandeperre et al. 2011) and biological and ecological benefits, such as greater abundance and larger body sizes of targeted species, in association with MPAs (Lester et al. 2009, Sciberras et al. 2013). However, the design of reserve studies are often lacking, as before and after impact data are relatively rare (but see Alemany et al. 2013, Rife et al. 2013), and environmental and habitat effects are often not considered (Lester et al. 2009, 
Miller and Russ 2014). Furthermore, few studies to date have explicitly assessed quantitative impacts of MPAs on reproductive output through time.

Augmentation of reproductive output is critical to MPA success because larval export can seed surrounding areas and thus increase regional production (Halpern et al. 2009, Pelc et al. 2009, Russ and Alcala 2011). In this study we evaluate reserve effects on rockfish (Sebastes spp.) production throughout southern California using a before-after, control impact paired series design approach (Schmitt and Osenberg 1996).

Rockfishes (Sebastes spp.) are a speciose group of demersal fishes found mostly along the west coast of North America. Whereas some species are relatively small and short-lived and provide an important forage base for predatory fishes and marine mammals, others grow to large sizes $(>90 \mathrm{~cm})$, live for many decades (up to > 150 years), and are apex predators (Love et al. 2002). Larger rockfish species have been targeted by recreational and commercial fisheries since the mid- $19^{\text {th }}$ century, and technological developments in the $1940 \mathrm{~s}$ and 1970s led to severe population declines due to overfishing (Love et al. 2002). A survey of commercial passenger fishing vessels in the Southern California Bight (SCB) region from 1980 to 1996 revealed drastic declines in CPUE and mean total length of multiple rockfish species, such as Bocaccio (S. paucispinis), Blue (S. mystinus), Olive (S. serranoides), Chilipepper (S. goodei), Swordspine (S. ensifer), Yellowtail (S. flavidus), and Vermilion rockfishes (S. miniatus) (Love et al. 1998). Moser et al. (2000) observed declines in larval abundances associated with declines in adult biomass of Bocaccio and Cowcod (S. levis) in 
fishery-independent surveys from 1977-1998. Moser et al. (2000) suggested environmental conditions (i.e., a shift to a warm climate regime at that time) and fishery exploitation as possible explanatory factors for the declines; however, a later study determined that the regime shift did not significantly impact $S$. paucispinis recruitment, supporting the idea that the declines were more likely due to fishery exploitation (Tolimieri and Levin 2005).

In 2001, in response to the drastic decline in populations of rockfishes in Southern California, [particularly S. levis, which was formally declared overfished in 1999 (Butler et al. 1999)], the Pacific Fishery Management Council and the California Department of Fish and Game established two Cowcod Conservation Areas (CCAs). The CCAs comprise two areas in the SCB where bottom-fishing deeper than $36 \mathrm{~m}$ is prohibited — a larger western area encompassing roughly $10,878 \mathrm{~km}^{2}$, and a smaller area to the east encompassing roughly $260 \mathrm{~km}^{2}$ (Figure 1.2). These areas are several times larger than most other marine reserve areas that have been comprehensively studied thus far (but see Alemany et al. 2013). In this study we evaluate whether the CCAs impacted larval production of rockfishes over a 16-year period that spans before and after the CCAs' implementation.

Previous research has suggested that the CCAs have benefited targeted rockfishes (Hitchman et al. 2012, Stierhoff et al. 2013, Thompson et al. 2016). However, there have been no studies assessing how the CCAs have impacted targeted rockfishes over the entire reserve and throughout the duration of the CCAs' establishment. Both stock assessments (Dick and MacCall 2014, He et al. 2015) and ecological studies (Yoklavich et al. 2007, Thompson et al. 2012) 
conducted in and around the CCAs noted that the lack of time-series data hinders our capacity to understand whether the CCAs have influenced the recovery of rockfishes from overfishing.

By evaluating the efficacy of large marine reserves on fish reproductive output this study provides critical information for understanding MPA dynamics and assisting fisheries management. We analyze a unique fishery-independent time series of rockfish larvae collected annually from 1998 to 2013 within and outside of reserves before and after reserve establishment. The dataset includes species that are both targeted and untargeted by fishers as well as oceanographic and habitat conditions at systematically sampled locations. We are thus able to evaluate reserve effects while controlling for oceanographic dynamics.

\subsection{Methods}

\subsubsection{Sample collection and initial processing}

Ichthyoplankton samples have been collected quarterly in the SCB and preserved in $95 \%$ ethanol since 1997 as part of the California Cooperative Oceanic Fisheries Investigations (CalCOFI) sampling program (Fig 1.2).

CalCOFI uses $0.71 \mathrm{~m}$ diameter, $505 \mu \mathrm{m}$-mesh bongo nets towed obliquely to 210 m depth to collect ichthyoplankton samples (Ohman and Smith 1995, McClatchie 2014) and CTDs to record oceanographic variables (e.g., temperature, salinity, dissolved oxygen concentration, and chlorophyll a). This study focuses on samples collected from 1998 to 2013 during the winter (January-February) cruise as winter is the peak spawning period for the majority of rockfishes in this region 
(Love et al. 1990, Moser et al. 2001). Ichthyoplankton that were visually identified as rockfishes were removed, counted, and measured for total length with a dissecting microscope and micrometer.

\subsubsection{Species identification and data refinement}

A few rockfish species, such as S. jordani, S. paucispinis, and older stages of S. levis can be morphologically identified to the species level during the entire duration of their early life history stages, and these were enumerated visually under a microscope. The vast majority of rockfish larvae, however, are not identifiable to species based on morphology, and these were identified genetically by amplifying and sequencing the mitochondrial cytochrome $b$ gene [see Appendix 1 for protocol (Hyde and Vetter 2007, Thompson et al. 2016)]. Previous analyses demonstrated that this gene can discriminate all rockfish species in the SCB (Taylor et al. 2004, Thompson et al. 2016).

Unfortunately, most larvae from 2003 were found to be poorly preserved and thus unable to be sequenced; therefore, we excluded 2003 samples from the analyses. We also eliminated from analyses stations where greater than or equal to fifty percent of the larvae failed to sequence.

\subsubsection{Analyses}

Temporal trends

Trends in larval abundance were evaluated by correlating mean larval abundance per year against year with a general linear model. To standardize for 
minor differences in tow lengths and/or depths among stations, larval count data were multiplied by a standard haul factor (SHF) and expressed as larvae under $10 \mathrm{~m}^{2}$ of sea surface area (Smith and Richardson 1977, Thompson et al. 2016). Annual winter means were calculated using the delta-mean technique (Pennington 1983) that helps account for high numbers of samples containing zero values. Analyses were restricted to common species (at least 300 larvae under $10 \mathrm{~m}^{2}$ summed across all years). We removed S. diploproa because this species is known to primarily spawn in the summer and fall (Moser et al. 2001). We also removed an extreme outlier station in 2004 that contained abundances of S. levis, S. wilsoni, and S. paucispinis that were between approximately two and three times greater than the next highest station in the entire data set (Figure A.1). We calculated the proportion of species that were historically targeted and nontargeted by fishing [as defined by Love et al. (2002)] that increased significantly $(p<0.05)$ through time. Our goal was to determine if there were similar patterns across species rather than determine the significance of any one species; therefore, we did not apply a Bonferroni correction.

\section{Environmental influence}

In addition to cessation of fishing pressure, environmental conditions may have contributed to changes in larval rockfish abundances. To determine dynamic habitat preference for the common species, we utilized logistic regression to test whether the presence of larvae at each station was affected by temperature, chlorophyll a, salinity and oxygen. Covariance was low among these independent 
variables and all were included in the analyses (Table A.1). Because the vast majority of rockfish larvae occupy the upper $100 \mathrm{~m}$ of the water column (Ahlstrom 1959), we computed mean values for each environmental covariate between 3 and $100 \mathrm{~m}$. We limited these analyses to include only larvae that were $\leq 5 \mathrm{~mm}$ total length (TL) based on previous findings that these young larvae had mostly not been advected far from their natal location (Hitchman et al. 2012, Thompson et al. 2016). Residuals for each species model were not found to be spatially autocorrelated but were temporally autocorrelated (Figure A.2). To account for temporal autocorrelation we included year as an autocovariate; residuals of these models were not temporally autocorrelated (Figure A.3). We again calculated the proportion of targeted and untargeted species whose presence/absence correlated significantly $(\mathrm{p}<0.05)$ with a covariate.

To provide a sense of how oceanographic conditions during the study compared with long-term patterns, we calculated yearly winter averages of the environmental variables from the time-series data and compared them to longterm winter averages obtained from CalCOFI hydrographic data spanning from 1983 to 2013.

\section{CCA influence}

If the CCAs positively influenced rockfish production, larval abundances should have increased at a greater rate within than outside of the protected areas for targeted species but not for untargeted species. However, environmental conditions can also affect production dynamics, thereby obscuring reserve effects. 
To isolate CCA from environmental effects we conducted a Bray-Curtis cluster analysis on stations based on means of the four environmental variables (oxygen, chlorophyll a, temperature, and salinity) averaged across the time-series, as well as two stationary variables — depth and percentage of hard substrate - that are known to affect rockfish distribution (Love et al. 1990, Thompson et al. 2016): the proportion of hard substrate (obtained from the Seafloor Mapping Lab at California State University, Monterey Bay, http://seafloor. otterlabs.org/contact.html) and depth (Figure A.4). We then selected six stations outside of the protected areas that most closely matched habitat conditions of the six CCA stations (Figure A.4). Next, we calculated winter delta means for each species with a total abundance of $\geq 150$ larvae under $10 \mathrm{~m}^{2}$ during the study in these twelve stations alone: S. rufus, S. paucispinis, S. ovalis, and S. serranoides for the most abundant targeted species (while S. mystinus did meet this threshold, it was excluded from this analysis as its center of distribution was found to be north of the Channel Islands), and S. hopkinsi, S. jordani, S. wilsoni, S. saxicola, S. ensifer, and S. moseri for the most abundant non-targeted species. As with the previous analysis we only utilized individuals that were $\leq 5 \mathrm{~mm}$ TL. We then conducted an ANCOVA for each species with year, inside/outside the CCAs, and an interaction between these terms as the dependent variables. This interaction was particularly important as significance indicates that abundances changed at a different rate inside versus outside the CCA. We thus determined the proportion of targeted and untargeted species where the p-value for the year*CCA interaction was less than 0.05. All analyses and figures were made using the statistical 
analysis software R v.3.2.3 (R Development Core Team 2016). R packages are described in Appendix 3.

\subsection{Results}

Overview

We processed 6919 larvae and identified 38 rockfish species throughout the time-series (Table A.2). Two non-targeted species, S. hopkinsi and S. jordani, were especially predominant, comprising over $50 \%$ of the sequenced larvae combined. The next most abundant non-targeted species other than S. hopkinsi and S. jordani were S. wilsoni, S. semicinctus, S. saxicola, S. ensifer, and S. moseri (Table 2.1). The most abundant targeted species were $S$. paucispinis, $S$. mystinus, S. rufus, S. ovalis, S. serranoides, S. entomelas, S. goodei, and $S$. caurinus (Table 2.1). Conversely, some species were extremely rare. For example, we detected only one individual for $S$. chlorostictus, S. rosenblatti, and S. rubrivinctus, two individuals for $S$. dalli and S. ruberrimus, and three for $S$. macdonaldi (Table A.2).

\section{Temporal trends}

Thirty-five of the 38 species exhibited a positive (although not necessarily statistically significant) correlation with year (Figure A.5). Six of the eight most abundant targeted species (S. caurinus, S. entomelas, S. mystinus, S. ovalis, S. paucispinis, and S. serranoides) showed significant $(p<0.05)$ or nearly significant $(p<0.10)$ increases in their delta mean abundances over time. 
Interestingly, the namesake of the CCAs (S. levis) also increased significantly through time, but because its abundance throughout the study was below the established threshold (195 individuals under $10 \mathrm{~m}^{2}$, Figure 2.1), meaningful conclusions about $S$. levis larval dynamics are precluded. Four of the seven $(S$. hopkinsi, S. moseri, S. saxicola, and S. wilsoni) most abundant non-targeted species significantly or nearly significantly increased during the study (Figure 2.2).

\section{Environmental influence}

The probability of presence of five of the eight most abundant targeted species (S. entomelas, S. mystinus, S. ovalis, S. paucispinis, and S. serranoides) correlated negatively with temperature; of the seven most abundant non-targeted species, only S. moseri and S. wilsoni had significant negative relationships with temperature (Table 2.2, Figure A.6). There were also significant positive relationships with chlorophyll a for S. caurinus, $S$. jordani, and S. semicinctus (Table 2.2).

Comparison of average winter values of the environmental variables during the study period (1998 to 2013) to long-term averages (1983 to 2013) indicated that average winter temperature was frequently lower (11 out of 16 years), average winter salinity was frequently higher (10 out of 16 years), and average winter oxygen was frequently lower (10 out of 16 years) during the study (Figure 4). Average winter chlorophyll levels fluctuated nearly equally below and above 
the long-term winter average (seven years above, eight below, and one value nearly identical to the long-term average) (Figure 2.3).

\section{CCA influence}

The interaction between year and CCA was significant $(p<0.05)$ for two out of the four most abundant targeted species (S. ovalis, S. rufus) and nearly significant $(p<0.07)$ for $S$. serranoides (Figure 2.4). The interaction term was not significant ( $p$ between 0.17 and 0.99 ) for any of the most abundant untargeted species.

\subsection{Discussion}

Our results strongly suggest that the presence of large MPAs in California positively impacted reproductive output of targeted species. Abundances of $75 \%$ of the most common targeted species, but none of the untargeted species, increased at a greater rate at stations with similar habitats within than outside of the CCAs. This indicates that the presence of the CCAs is facilitating the recovery of rockfish species that were historically targeted by fishers.

Although it is recognized that augmenting reproductive output is crucially important for MPA success (Pelc et al. 2009), to our knowledge this is the first demonstration that an MPA has affected larval production at relatively large spatial and temporal scales. A handful of studies, however, measured reproductive output in association with MPAs at smaller scales. Valles et al. (2001) surveyed a marine reserve and an adjacent fished area over a span of three 
months and found no reserve effect on fish larvae; they proposed this was due to hydrodynamic or biological features. Lopez-Sanz et al. (2009) surveyed an MPA for two seasons in 2003 and found high species richness and a high abundance of shorefish larvae, and concluded that vulnerable species were recovering due to the reserve. Other studies that showed reserve benefits on reproductive output focused on increased number of eggs and larvae of conch species (Stoner and Ray 1997, Manriquez and Castilla 2001) or utilized proxies of reproductive output that were estimated from biological characteristics of the adult populations, such as organism size, fecundity, and biomass (Willis et al. 2003, Beukers-Stewart et al. 2005, Díaz et al. 2011). We suggest that more effort needs to be placed on directly quantifying larvae productivity to better assess the efficacy of MPAs.

Short-term studies also suggest that the CCAs benefit rockfish populations. Thompson et al. (2016) showed that larval rockfish species richness, particularly of targeted species, was higher within than outside of the CCAs in 2005. Similarly, Stierhoff et al. (2013) encountered greater numbers of S. levis within the CCAs than outside using submersible surveys. In addition, Hitchman et al. (2012) found that abundances of recently hatched larval S. paucispinis were concentrated around the relatively shallow banks within the eastern CCA. Although we did not detect an interaction between year and CCA for $S$. paucispinis, abundances were higher within than outside of paired CCA stations in all but two years. These studies and ours indicate that the CCAs were positioned in locations that are well suited to protect and facilitate the recovery of many rockfishes in southern California. 
Relatively large Rockfish Conservation Areas (RCAs) have also been established along the western U.S. coast, as well as further north in Canadian waters in the vicinity of British Columbia and Vancouver. These RCAs in the U.S. appear to be benefitting rockfishes in addition to other demersal species as bottom trawl surveys detected significant increases in abundances between 2003 and 2011 (Keller et al. 2014). Specifically, mean catch-per-unit-effort and organism sizes for a majority of observed species were higher in areas continuously closed to commercial trawling compared to areas open or periodically closed to trawling. However, studies in the Canadian RCAs obtained mixed results. Cloutier (2011) indicated that the Canadian RCAs in the Strait of Georgia were positively impacting rockfishes, but other research by Markel (2011) in Barkley Sound and Haggarty $(2015,2016)$ around Vancouver Island (including in the Strait of Georgia) suggested that the Canadian RCAs in these areas are not facilitating recovery of demersal fish populations within the reserves. Haggarty suggested that confounding factors such as habitat quality, habitat isolation, and level of fishing compliance, which she found to be unchanged or even increased in certain areas (Haggarty 2015, Haggarty 2016), have compromised RCA efficacy around Vancouver Island.

While larval rockfish abundances (and larval fish abundances in general) can be driven by multiple factors, it is likely that increased biomass of reproductively active females and favorable environmental conditions contributed to the larval abundance dynamics observed in our study. We found that larval abundances of the majority of both targeted and non-targeted rockfishes increased throughout the 
SCB between 1998 and 2013. Increasing adult rockfish abundances were also documented in stock assessments on S. levis in the SCB and S. paucispinis along the western U.S. coast (Dick and MacCall 2014, He et al. 2015). These trends were probably influenced by an exceptionally strong recruitment for most species in 1999 (Ralston et al. 2013). Given that management limited fishing beginning in 2000, it is probable that a relatively large proportion of the 1999 cohort survived long enough to begin becoming reproductively active and contributed to larval production by 2004 .

In addition to management actions that allowed more individuals to reach maturity, environmental conditions likely contributed to the proliferation of rockfish larvae. Rockfish spawning output is affected by the environment as female reproduction is reduced when food is scarce and adult energy reserves are low (Love et al. 2002). Low spawning years typically occur during El Niños when water temperature is high and primary productivity is low (Ventresca et al. 1995, Tolimieri and Levin 2005). Our logistic regression models indicate that the presence of most species correlated negatively with temperature. Further, we found that the water was cooler than the 30-year average in most years between 1998 and 2013, and it has been speculated that 1999 marked the beginning of an oceanographic shift from warm conditions that characterized the region between 1977 and 1998 (Zwolinski and Demer 2012). Therefore, environmental conditions appeared to have been generally conducive for high larval production and recruitment throughout much of the study. 
Although overfishing remains a global concern (Worm et al. 2009), synergistic effects of management and favorable environmental conditions have been identified to augment the recovery of another long-lived, overfished species (Petitgas et al. 2010). Striped Bass (Morone saxatilis) in the Chesapeake Bay, USA, were severely overfished throughout the 1970s and 1980s. In 1984 a strict fishing moratorium was implemented, and favorable environmental conditions produced strong recruitment in 1989, 1993, and 1996 (Field 1997, Secor 2000). By 2000, the stock was rebuilt to pre-exploitation levels (Secor 2000). It is possible that targeted rockfishes in southern California are on a similar trajectory.

Increasing larval rockfish abundances in the CCAs hold the potential to positively affect rockfish populations at a regional scale through larval spillover (Pelc et al. 2009). Future research using larvae from this study will concentrate on ageing larvae by counting daily otolith rings. Once precise ages are established we will use regional oceanic modeling systems (ROMS) models (Weber et al. 2015) to trace the path larvae took to arrive at their location of capture. This work will help better establish the degree to which the CCAs are functioning as sources in rockfish metapopulations.

Although the abundances of several species increased over the time-series (Fig A.5), abundances of multiple targeted species, notably including S. levis, remained at low levels relative to the non-targeted species. It is possible that not enough time has elapsed for effects to be seen in some targeted species populations. White et al. (2013) showed that it may take decades for a targeted fish species to reach an equilibrium following reserve establishment, especially if 
the populations in question have experienced high fishing pressure, undergo maturation at older ages, have lower natural mortality rates, and lower larval connectivity, most of which are characteristic of targeted rockfish species in our study. This idea was supported by García-Rubies et al. (2013) who further confirmed that exploited fish populations may need decades to recover, and that recovery rates differ among species. Further monitoring is needed to evaluate whether larval abundances of targeted rockfishes continue to increase relative to non-targeted species after 2013.

Alternatively, the system could be in an alternate stable state, having transitioned from being dominated by larger targeted rockfish species to being dominated by smaller, faster-growing, non-targeted species, namely $S$. hopkinsi and S. jordani (Baskett et al. 2006). If this is the case, the smaller species may be consuming young targeted species and hence directly impeding recovery. Another alternative is that potential ongoing fishing effort in the region and lack of enforcement could be maintaining low population numbers of targeted species that did not show similar trends of recovery. In order to assess this, future research on fishing effort in the region needs to be conducted. It is also possible that all of these scenarios may be interacting with each other to various degrees.

Our work strongly indicates that the CCAs have been effective in facilitating the recovery of multiple targeted rockfish species, supporting and highlighting the effectiveness of establishing and regularly monitoring long-term marine reserves. Given that augmenting larval output is the primary mechanism by which MPAs 
can benefit fisheries, we believe that larval monitoring should be utilized more often when assessing MPA efficacy. 
Table 2.1 Total standard haul factor-adjusted abundances (larvae under $10 \mathrm{~m}^{2}$, rounded to the nearest whole integer) of larvae for the most abundant rockfish species throughout the time series. 


\begin{tabular}{|l|cc|}
\hline & Fishery Importance & Total abundance \\
\hline S. caurinus & targeted & 314 \\
S. entomelas & $"$ & 340 \\
S. goodei & $"$ & 703 \\
S. mystinus & $"$ & 1505 \\
S. ovalis & $"$ & 756 \\
S. paucispinis & $"$ & 1251 \\
S. rufus & $"$ & 972 \\
S. serranoides & $"$ & 417 \\
\hline S. ensifer & non-targeted & 493 \\
S. hopkinsi & $"$ & 9104 \\
S. jordani & $"$ & 6884 \\
S. moseri & $"$ & 373 \\
S. saxicola & $"$ & 1008 \\
S. semicinctus & $"$ & 1357 \\
S. wilsoni & $"$ & 1807 \\
\hline
\end{tabular}


Table 2.2 Slopes of relationships between rockfish species presence and environmental variables over the study period. Significant relationships $(p<$ 0.05 ) are indicated in bold. The horizontal line distinguishes between targeted and non-targeted species. 


\begin{tabular}{|l|cccc|}
\hline & Temperature & Salinity & Oxygen & Chlorophyll a \\
\hline S. caurinus & -0.556 & 0.773 & 0.376 & $\mathbf{0 . 4 6 4}$ \\
S. entomelas & $\mathbf{- 0 . 8 5 5}$ & -1.284 & 0.516 & 0.001 \\
S. goodei & -0.2 .81 & $\mathbf{- 3 . 2 9 7}$ & -0.836 & -0.095 \\
S. mystinus & $\mathbf{- 1 . 0 9 0}$ & -0.351 & $\mathbf{1 . 0 3 5}$ & 0.250 \\
S. ovalis & $\mathbf{- 0 . 4 6 0}$ & -0.492 & 0.179 & 0.111 \\
S. paucispinis & $\mathbf{- 0 . 7 5 8}$ & -1.312 & 0.376 & -0.038 \\
S. rufus & -0.129 & 0.253 & 0.545 & -0.203 \\
S. serranoides & $\mathbf{- 0 . 6 3 3}$ & -1.122 & 0.249 & 0.143 \\
\hline S. ensifer & 0.035 & $\mathbf{3 . 2 0 0}$ & 0.358 & -0.423 \\
S. hopkinsi & -0.198 & 0.067 & -0.492 & 0.266 \\
S. jordani & -0.022 & -1.257 & $\mathbf{- 1 . 3 0 1}$ & $\mathbf{0 . 4 7 0}$ \\
S. moseri & $\mathbf{- 0 . 6 8 7}$ & -0.266 & 0.937 & -1.44 \\
S. saxicola & -0.140 & -0.837 & -0.540 & 0.267 \\
S. semicinctus & 0.165 & -1.926 & $\mathbf{- 1 . 2 2 9}$ & $\mathbf{0 . 5 7 0}$ \\
S. wilsoni & $\mathbf{- 0 . 7 7 3}$ & -0.759 & 0.137 & -0.036 \\
\hline
\end{tabular}


Figure 2.1 Delta mean abundances of the eight most abundant rockfishes that were historically targeted by fishing pressure through time. Of these eight, $S$. caurinus, S. entomelas, S. mystinus, S. ovalis, S. paucispinis, and S. serranoides showed significant or nearly significant increases. Sebastes levis did not meet the abundance criteria to be included in the statistical analysis, but is shown here as it is the namesake of the marine protected area. 

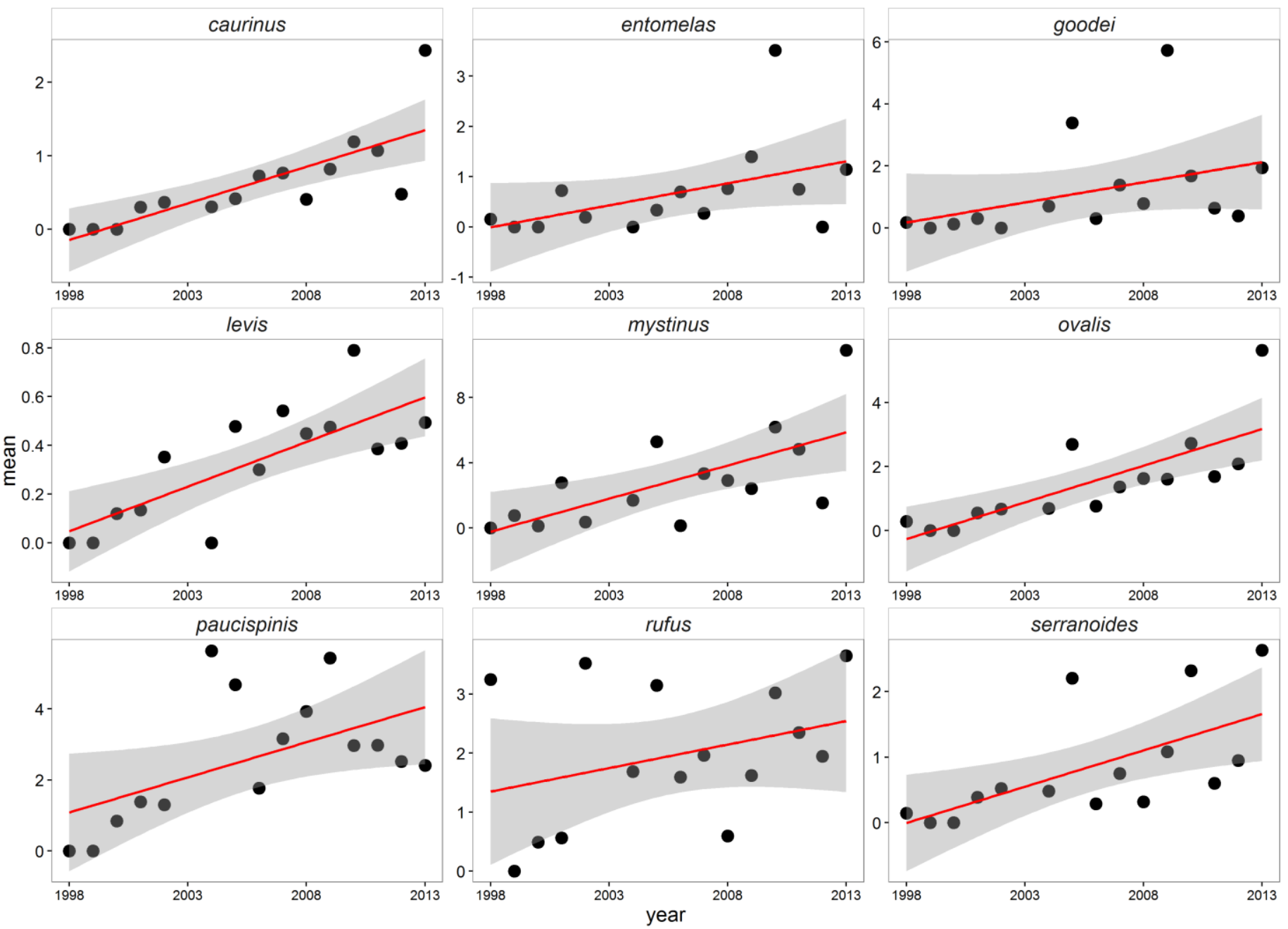
Figure 2.2 Delta mean abundances through time of the seven most abundant rockfishes that were not targeted by fishing. Of these seven, S. hopkinsi, $S$. moseri, S. saxicola, and S. wilsoni showed significant or nearly significant increases. 


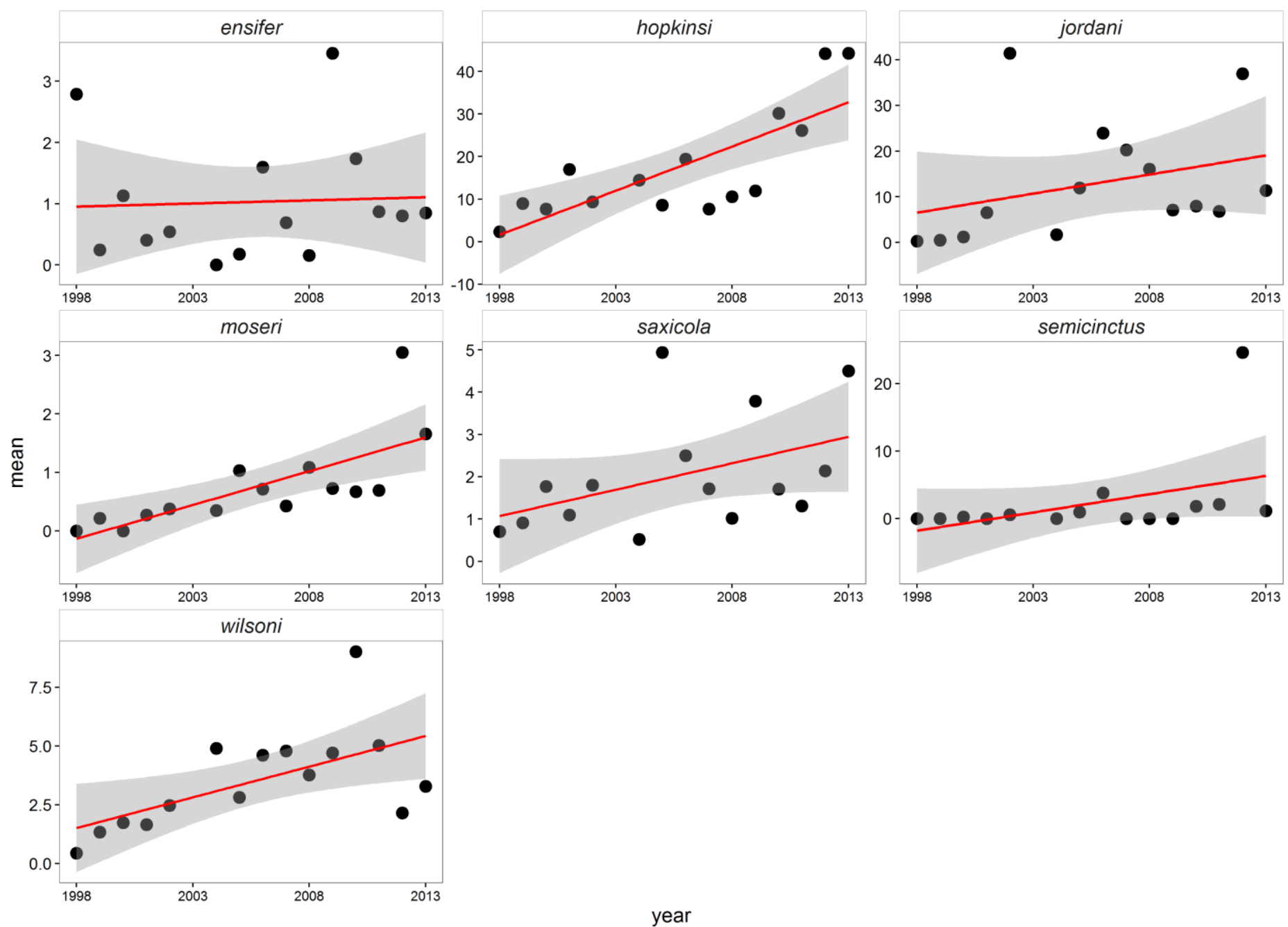


Figure 2.3 Mean winter environmental variable values over the course of the study period (temperature measured in degrees Celsius, salinity in ppt, oxygen in $\mathrm{ml} / \mathrm{L}$, and chlorophyll a in $\mu \mathrm{g} / \mathrm{L})$. Long-term winter averages from 1983 to 2013 are indicated by dotted blue lines. 


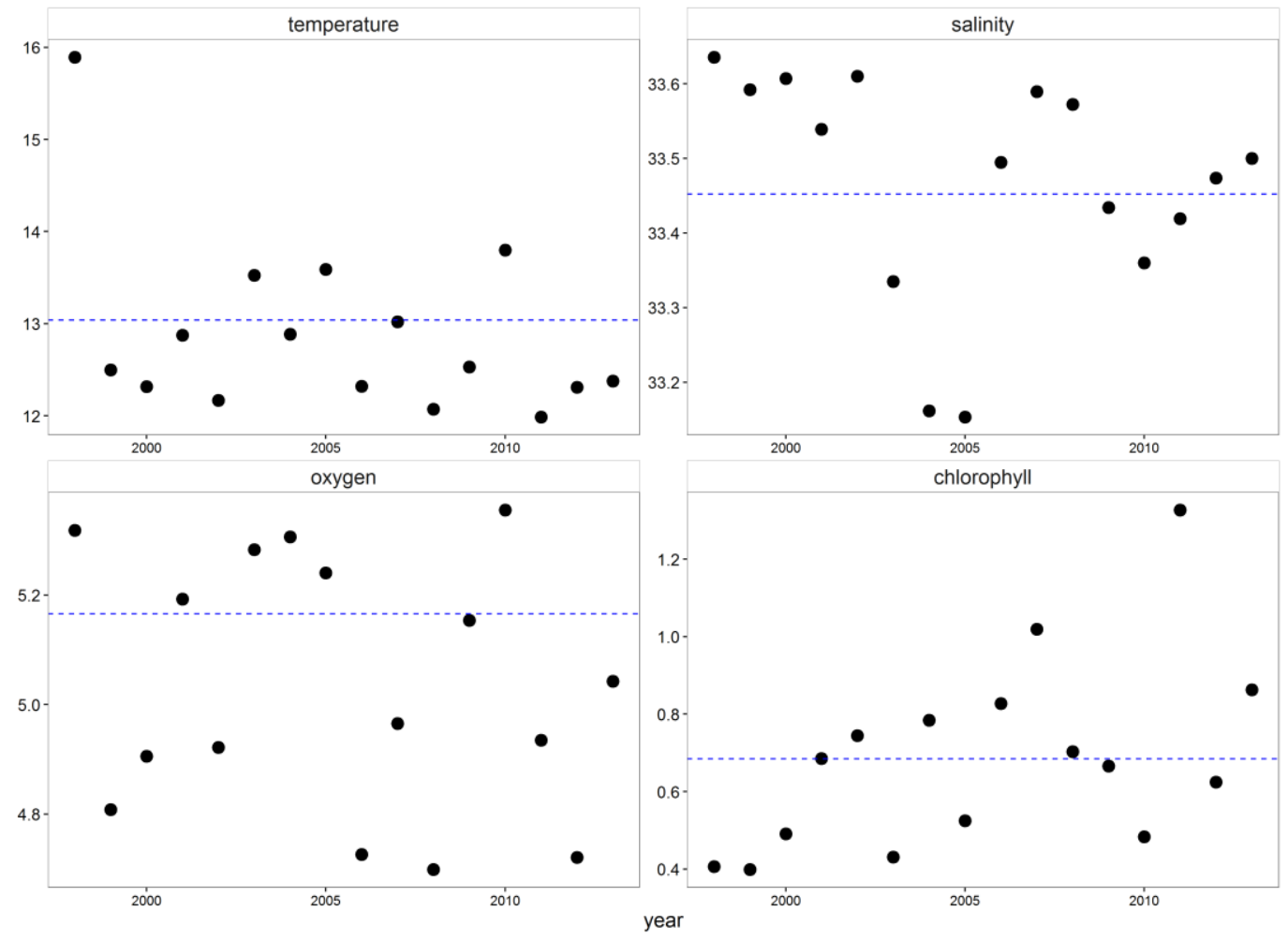


Figure 2.4 Larval abundance trends of targeted species within the CCAs (red) and outside of the CCAs (blue). 


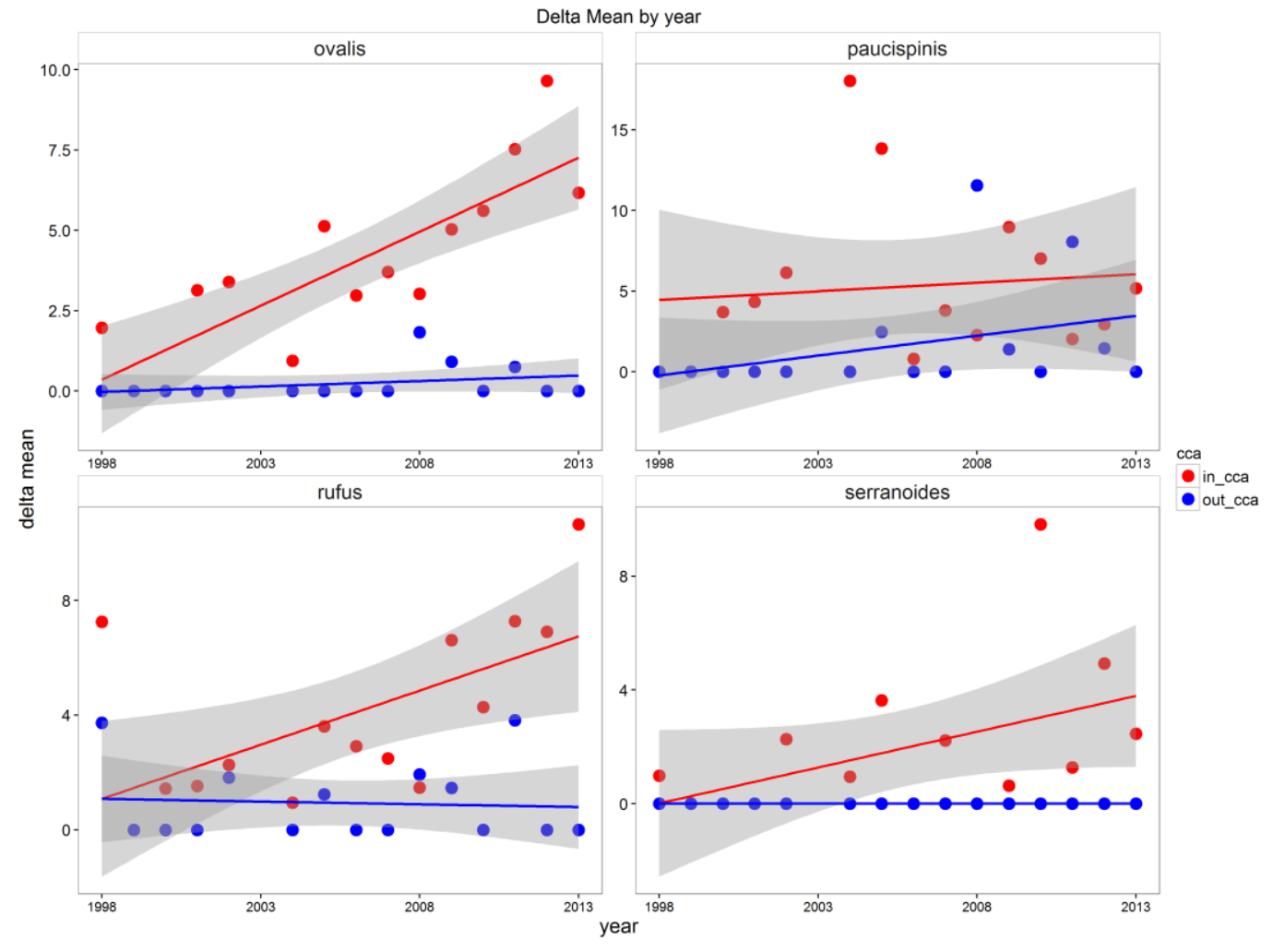




\section{References}

1. AHLSTROM, E.H. 1959. Vertical distribution of pelagic fish eggs and larvae off California and Baja California. U.S. Fishery Bulletin 60:107-146.

2. ALEMANY, D., Iribarne, O.O., and E.M. Acha. 2013. Effects of a large-scale and offshore marine protected area on the demersal fish assemblage in the Southwest Atlantic. ICES Journal of Marine Science 70:123-134.

3. BADDELEY, A., Rubak, E., and R. Turner 2015. Spatial Point Patterns: Methodology and Applications with R. London: Chapman and Hall/CRC Press, 2015.

4. BASKETT, M.L. Yoklavich, M., and M.S. Love. 2006. Predation, competition, and the recovery of overexploited fish stocks in marine reserves. Canadian Journal of Fisheries and Aquatic Sciences 63(6):1214-1229.

5. BEUKERS-STEWART, B.D., Vause, B.J., Mosely, M., Rossetti, H.L., and A.R. Brand. 2005. Benefits of closed area protection for a population of scallops. Marine Ecology Progress Series 298:189-204.

6. BIVAND, R.S., Pebesma, E., and V. Gomez-Rubio. 2013. Applied spatial data analysis with R. Springer, New York, NY.

7. BIVAND, R. and N. Lewin-Koh. 2016. Maptools: Tools for Reading and Handling Spatial Objects. R package version 0.8-39. https:/CRAN.Rproject.org/package=maptools

8. BIVAND, R., Keitt, T., and B. Rowlingson. 2016. Rgdal: Bindings for the Geospatial Data Abstraction Library. R package version 1.1-10. https://CRAN.R-project.org/package=rgdal 
9. BIVAND, R., and C. Rundel. 2016. Rgeos: Interface to Geometry Engine Open Source (GEOS). R package version 0.3-20. https://CRAN.Rproject.org/package $=$ rgeos

10. BJORNSTAD, O.N. 2013. ncf: spatial nonparametric covariance functions. $R$ package version 2.8.0 https://cran.r-project.org/web/packages/ncf/index.html.

11. BUTLER, J.L., L.D. Jacobson, J.T. Barnes, H.G. Moser, and R. Collins. 1999. Stock assessment of cowcod. Pacific Fishery Management Council. Web. 26 Apr 2014. < http:// www.pcouncil.org/wpcontent/uploads/Cowcod_1999_Assessment.pdf>

12. CHRISTENSEN, V., Coll, M., Piroddi, C., Steenbeek, J., Buszowski, J., and D. Pauly. 2014. A century of fish biomass decline in the ocean. Mar. Ecol. Prog. Ser. 512: 155-166.

13. CLOUTIER, R.N. 2011. Direct and indirect effects of marine protection: Rockfish Conservation Areas as a case study. M.Sc. thesis. Simon Fraser University.

14. DE VRIES, A., and B.D. Ripley. 2016. Ggdendro: Create Dendrograms and Tree Diagrams Using 'ggplot2'. R package version 0.1-20. https://CRAN.Rproject.org/package=ggdendro

15. DÍAZ, D., Mallol, S., Parma, A.M., and R. Goñi. 2011. Decadal trend in lobster reproductive output from a temperate marine protected area. Marine Ecology Progress Series 433:149-157. 
16. DICK, E.J. and A.D. MacCall. 2014. Status and productivity of cowcod, Sebastes levis, in the Southern California Bight, 2013. Pacific Fishery Management Council, Portland, OR.

17. DOWLE, M., Srinivasan, A., Short, T., Lianoglou, S., Saporta, R., and E. Antonyan. 2015. Data.table: Extension of Data.frame. R package version 1.9.6. https://CRAN.R-project.org/package=data.table

18. FIELD, J.D. 1997. Atlantic striped bass management: where did we go right? Fisheries 22:6-8.

19. GARCÍA-RUBIES, A., Hereu, B., and M Zabala. 2013. Long-term recovery patterns and limited spillover of large predatory fish in a Mediterranean MPA. PloS one 8(9): e73922.

20. HAGGARTY, D.R. 2015. An evaluation of the effectiveness of Rockfish Conservation Areas in British Columbia, Canada. Ph.D. dissertation. University of British Columbia.

21. HAGGARTY, D.R. 2016. Assessing population recovery inside British Columbia's Rockfish Conservation Areas with a remotely operated vehicle. Ph.D. dissertation. University of British Columbia.

22. HALPERN, B.S., Lester, S.E., and J.B. Kellner. 2009. Spillover from marine reserves and the replenishment of fished stocks. Environmental Conservation 36(4): 268-276.

23. HE, X., Field, J.C., Pearson, D.E., Lefebvre, L., and S. Lindley. 2015. Status of Bocaccio, Sebastes paucispinis, in the Conception, Monterey and Eureka INPFC areas for 2015. Pacific Fishery Management Council, Portland, OR. 
24. HITCHMAN, S.M., N.B. Reyns, and A.R. Thompson. 2012. Larvae define spawning habitat of bocaccio rockfish Sebastes paucispinis within and around a large southern California marine reserve. Marine Ecology Progress Series 465: 227-242.

25. HYDE, J.R. and R.D. Vetter. 2007. The origin, evolution, and diversification of rockfishes of the genus Sebastes (Cuvier). Molecular Phylogenetics and Evolution 44:790-811.

26. JACKSON, J.B.C., M.X. Kirby, W.H. Berger, K.A. Bjorndal, L.W. Botsford, B.J. Bourque, R.H. Bradbury, R. Cooke, J. Erlandson, J.A. Estes, T.P. Hughes, S. Kidwell, C.B. Lange, H.S. Lenihan, J.M. Pandolfi, C.H. Peterson, R.S. Steneck, M.J. Tegner, and R.R. Warner. 2001. Historical Overfishing and the Recent Collapse of Coastal Ecosystems. Science 293: 629-638.

27. KAHLE, D., and H. Wickham. 2013. ggmap: spatial visualization with ggplot 2. R J 5:144-161.

28. KELLER, A.A., Wakefield, W.W., Whitmire, C.E., Horness, B.H., Bellman, M.A., and K.L. Bosley. 2014. Distribution of demersal fishes along the US west coast (Canada to Mexico) in relation to spatial fishing closures (20032011). Marine Ecology Progress Series 501:169-190.

29. LESTER, S.E., B.S. Halpern, K. Grorud-Colvert, J. Lubchenco, B.I. Ruttenberg, S.D. Gaines, S. Airamé, and R.R. Warner. 2009. Biological effects within no-take marine reserves: a global synthesis. 2009. Marine Ecology Progress Series 384: 33-46. 
30. LÓPEZ-SANZ, À., Vert, N., Zabala, M., and A. Sabatés. 2009. Small-scale distribution of fish larvae around the Medes Islands marine protected area (NW Mediterranean). Journal of Plankton Research fbp024.

31. LOVE, M.S., Morris, P., McCrae, M., and R. Collins. 1990. Life history aspects of 19 rockfish species (Scorpaenidae: Sebastes) from the Southern California Bight. NOAA Technical Report NMFS 87.38 pp.

32. LOVE, M.S., Caselle, J.E., and W.V. Buskirk. 1998. A severe decline in the commercial passenger fishing vessel rockfish (Sebastes spp.) catch in the Southern California Bight, 1980-1996. CalCOFI Report 39: 180-195.

33. LOVE, M.S., Yoklavich, M.M., and L. Thorsteinson. 2002. The Rockfishes of the Northeast Pacific. University of California Press, Berkeley and Los Angeles, 404 pp.

34. MADIN, E.M.P., Lawrence, M.D., Ridlon, A.D., Heithaus, M.R., and R.R. Warner. 2016. Human activities change marine ecosystems by altering predation risk. Global Change Biology 22(1): 44-60.

35. MANRIQUEZ, P.H. and J.C. Castilla. 2001. Significance of marine protected areas in central Chile as seeding grounds for the gastropod Concholepas concholepas. Marine Ecology Progress Series 215:201-211.

36. MARKEL, R.W. 2011. Rockfish recruitment and trophic dynamics on the west coast of Vancouver Island: fishing, ocean climate, and sea otters. Ph.D. dissertation. University of British Columbia.

37. MCCLATCHIE, S. 2014. Regional Fisheries Oceanography of the California Current System. Springer Netherlands. 
38. MCILROY, D., Brownrigg, R., Minka, T.P., and R. Bivand. 2015. Mapproj: Map Projections. R package version 1.2-4. https://CRAN.Rproject.org/package=mapproj

39. MENDELSSOHN, R. 2016. Xtractomatic: Accessing Environmental Data from ERD’s ERDDAp Server. R package version 3.1.1. https://CRAN.Rproject.org/package $=$ xtractomatic

40. MILLER, K.I. and G.R. Russ. 2014. Studies of no-take marine reserves: Methods for differentiating reserve and habitat effects. Ocean \& Coastal Management 96:51-60.

41. MOSER, H.G., Charter, R.L., Watson, W., Ambrose, D.A., Butler, J.L., Charter, S.R., and E.M. Sandknop. 2000. Abundance and distribution of rockfish (Sebastes) larvae in the Southern California Bight in relation to environmental conditions and fishery exploitation. CalCOFI Report 41:32-47.

42. MOSER, H.G., Charter, R.L., Watson, W., Ambrose, D.A., Hill, K.T., Smith, P.E., Butler, J.L., Sandknop, E.M., and S.R. Charter. 2001. The CalCOFI ichthyoplankton time series: potential contributions to the management of rocky-shore fishes. CalCOFI Report 42:112-128.

43. MYERS, R.A. and B. Worm. 2003. Rapid worldwide depletion of predatory fish communities. Nature 423: 280-283.

44. NELSON, G.A. 2016. Fishmethods: Fishery Science Methods and Models in R. R package version 1.10-0. https://CRAN.Rproject.org/package=fishmethods 
45. OHMAN, M. and P. Smith. 1995. A comparison of zooplankton sampling methods in the CalCOFI time series. CalCOFI Report 36: 153-158.

46. OKSANEN, J., Guillaume Blanchet, F., Friendly, M., Kindt, R., Legendre, P. McGlinn, D., Minchin, P.R., O’Hara, R.B., Simpson, G.L., Solymos, P., Stevens, M.H.H., Stevens, Szoecs, E., and H. Wagner. 2016. vegan:

Community Ecology Package. R package version 2.4-1. https://CRAN.Rproject.org/ package=vegan

47. PELC, R.A., Warner, R.R., Gaines, S.D., and C.B. Paris. 2009. Detecting larval export from marine reserves. PNAS 107(43):18266-18271.

48. PENNINGTON, M. 1983. Estimating the mean and variance from highly skewed marine data. Fishery Bulletin 94:498-505.

49. PETITGAS, P., Secor, D.H., McQuinn, I., Huse, G., and N. Lo. 2010. Stock collapses and their recovery: mechanisms that establish and maintain lifecycle closure in space and time. ICES Journal of Marine Sciences 67:18411848.

50. PITCHER, T.J. and W.W.L. Cheung. 2013. Fisheries: Hope or despair? Marine Pollution Bulletin 74(2): 506-516.

51. RALSTON, S., Sakuma, K.M., and J.C. Field. 2013. Interannual variation in pelagic juvenile rockfish (Sebastes spp.) abundance - going with the flow. Fisheries Oceanography 22(4):288-308.

52. RIFE, A.N., Aburto-Oropeza, O., Hastings, P.A., Erisman, B., Ballantyne, F., Wielgus, J., Sala, E., and L. Gerber. 2013. Long-term effectiveness of a multi- 
use marine protected area on reef fish assemblages and fisheries landings. Journal of Environmental Management 117:276-283.

53. ROBERTS, C.M., J.A. Bohnsack, F. Gell, J.P. Hawkins, and R. Goodridge. 2001. Effects of marine reserves on adjacent fisheries. Science 294(5548): 1920-1923.

54. RUSS, G.R. and A.C. Alcala. 2011. Enhanced biodiversity beyond marine reserve boundaries: The cup spillith over. Ecological Applications 21(1):241250.

55. SARKAR, D. 2008. Lattice: Multivariate Data Visualization with R. Springer, New York. ISBN 978-0-387-75968-5

56. SARKAR, D. and F. Andrews. 2016. LatticeExtra: Extra Graphical Utilities Based on Lattice. R package version 0.6-28. https://CRAN.Rproject.org/package=latticeExtra

57. SCHMITT, R.J. and C.W. Osenberg. 1996. Detecting ecological impacts: concepts and applications in coastal habitats. Academic Press.

58. SCHNUTE, J.T. Boers, N., and R. Haigh. 2015. PBSmapping: Mapping Fisheries Data and Spatial Analysis Tools. R package version 2.69.76. https://CRAN.R-project.org/package=PBSmapping

59. SCIBERRAS, M., Jenkins, S.R., Kaiser, M.J., Hawkins, S.J., and A.S. Pullin. 2013. Evaluating the biological effectiveness of fully and partially protected marine areas. Environmental Evidence 2(1): 4.

60. SECOR, D.H. 2000. Longevity and resilience of Chesapeake Bay striped bass. ICES Journal of Marine Sciences 57:808-815. 
61. SMITH, P.E. and S.L. Richardson. 1977. Standard techniques for pelagic fish egg and larva surveys. FAO Fish Tech Pap 175:1-99.

62. STIERHOFF, K.L., Mau, S.A., and D.W. Murfin. 2013. A fisheryindependent survey of cowcod (Sebastes levis) in the Southern CA Bight using a remotely operated vehicle (ROV).

63. STONER, A.W. and M. Ray. 1997. Queen conch, Strombus gigas, in fished and unfished locations of the Bahamas: effects of a marine fishery reserve on adults, juveniles, and larval production. Oceanographic Literature Review 5(44):515-516.

64. TAMURA, K. Stecher, G., Peterson, D., Filipski, A., and S. Kumar. 2013. MEGA6: molecular evolutionary genetics analysis version 6.0. Mol. Biol. Evol. 30:2725-2729.

65. TAYLOR, C.A., Watson, W., Chereskin, T., Hyde, J., and R. Vetter. 2004. Retention of larval rockfishes, Sebastes, near natal habitat in the Southern California Bight, as indicated by molecular identification methods. CalCOFI Report 45:152-166.

66. THOMPSON, A.R., W.W. Watson, S. McClatchie, and E.D. Weber. 2012. Multi-scale sampling to evaluate assemblage dynamics in an oceanic marine reserve. PloS ONE 7:e33131.

67. THOMPSON, A.R., Hyde, J.R., Watson, W., Chen, D.C., and L.W. Guo. 2016. Rockfish assemblage structure and spawning locations in southern California identified through larval sampling. Mar Ecol Prog Ser 547:177192. 
68. TOLIMIERI, N. and P.S. Levin. 2005. The roles of fishing and climate in the population dynamics of bocaccio rockfish. Ecological Applications 15(2): $458-468$

69. URBANEK, S. 2013. png: Read and write PNG images. R package version 0.1-7. https://CRAN.R-project.org/package=png

70. VALLES, H., Sponaugle, S., and H.A. Oxenford. 2001. Larval supply to a marine reserve and adjacent fished area in the Soufriere Marine Management Area, St Lucia, West Indies. Journal of Fish Biology 59(sA):152-177.

71. VANDEPERRE, F., Higgins, R.M., Sánchez-Meca, J., Maynou, F., Goñi, R., Martín-Sosa, P., Pérez-Ruzafa, A., Afonso, P., Bertocci, I., Crec’hriou, R., D’anna, G., Dimech, M., Dorta, C., Esparza, O., Falcón, J.M., Forcada, A., Guala, I., Le Direach, L., Marcos, C., Ojeda-Martínez, C., Pipitone, C., Schembri, P.J., Stelzenmüller, V., Stobart, B., Santos, R.S. 2011. Effects of no-take area size and age of marine protected areas on fisheries yields: a metaanalytical approach. Fish and Fisheries 12(4): 412-426.

72. VENABLES, W.N., and B.D. Ripley. 2002. Modern applied statistics with S. Springer, New York, NY.

73. VENTRESCA, D.A., Parrish, R.H., Houk, J.L., Gingras, M.L., Short, S.D., and N.L. Crane. 1995. El Niño effects on the somatic and reproductive condition of blue rockfish, Sebastes mystinus. CalCOFI Report 36:167-174.

74. WEBER, E.D., Chao, Y., Chai, F., and S. McClatchie. 2015. Transport patterns of Pacific sardine Sardinops sagax eggs and larvae in the California Current System. Deep-Sea Research I 100:127-139. 
75. WHITE, J.W., Botsford, L.W., Hastings, A., Baskett, M.L., Kaplan, D.M., and L.A. Barnett. 2013. Transient responses of fished populations to marine reserve establishment. Conservation Letters 6(3):180-191.

76. WICKHAM, H. 2007. Reshaping Data with the reshape Package. Journal of Statistical Software 21(12):1-20.

77. WICKHAM, H. 2009. ggplot2: elegant graphics for data analysis. Springer, New York, NY.

78. WICKHAM, H. 2011. The Split-Apply-Combine Strategy for Data Analysis. Journal of Statistical Software 40(1):1-29.

79. WILLIS, T.J., Millar, R.B., and R.C. Babcock. 2003. Protection of exploited fish in temperature regions: high density and biomass of snapper Pagrus auratus (Sparidae) in northern New Zealand marine reserves. Journal of Applied Ecology 40(2):214-227.

80. WORM, B., Hilborn, R., Baum, J.K., Branch, T.A., Collie, J.S., Costello, C., Fogarty, M.J., Fulton, E.A., Hutchings, J.A., Jennings, S., Jensen, O.P., Lotze, H.K., Mace, P.M., McClanahan, T.R., Minto, C., Palumbi, S.R., Parma, A.M., Ricard, D., Rosenberg, A.A., Watson, R., and D. Zeller. 2009. Rebuilding Global Fisheries. Science 325(5940):578-585.

81. YOKLAVICH, M.M., M.S. Love, and K.A. Forney. 2007. A fisheryindependent assessment of an overfished rockfish stock, cowcod (Sebastes levis), using direct observations from an occupied submersible. Canadian Journal of Fisheries and Aquatic Sciences 64(12): 1795-1804. 
82. ZWOLINSKI, J.P. and D.A. Demer. 2012. A cold oceanographic regime with high exploitation rates in the Northeast Pacific forecasts a collapse of the sardine stock. PNAS 109(11):4175-4180. 


\section{CHAPTER 3: CONCLUSION}

In this study I demonstrate that the CCAs positively impacted targeted rockfish species as larval abundances of targeted rockfish species increased at a greater rate through time within the CCAs compared to stations with similar environmental conditions, depth, and substrate type outside of the CCAs. In contrast, I found that the rates of change within vs. outside of the CCAs were similar for non-targeted species. These results hold important implications for MPA studies as a whole, as they demonstrate explicit increase in reproductive output of targeted species through time in association with MPA establishment (see Section 2.5 for more detailed framing of this study within the context of other MPA studies). Additionally, this study also represents the first systematic spatiotemporal assessment of the CCAs' impacts on rockfish populations and therefore holds important implications for fisheries management of rockfish fisheries in southern California. This is especially the case since it is possible that S. paucispinis and S. levis fisheries will be re-opening in the near future, as both of their stocks are likely to rebuild "faster than expected" (John Field, personal communication).

This study also provides an important resource for rockfish fisheries management through the conception of a comprehensive fisheries-independent spatiotemporal dataset of larval abundances of the suite of rockfish species sampled during the CalCOFI cruises. This information can be incorporated into the rockfish stock assessments conducted by the Pacific Fishery Management Council. There are around 20 species for which stock assessments are either kept 
up to date or have at least been conducted at some point in the past; these include species that were relatively abundant in this study, such as $S$. diploproa, $S$. entomelas, S. goodei, S. jordani, S. levis, S. mystinus, S. paucispinis, and S. rufus. This dataset is currently restricted to the ethanol-preserved mesozooplankton samples from the winter CalCOFI cruises spanning from 1998 to 2013, but it can also be expanded to include samples leading up to the present year, as well as samples collected during cruises from other seasons; spring samples would be especially valuable to include, as some species' peak parturition periods occur in the spring months (Love et al. 2002). For the few visually identifiable species (which notably include S. levis and S. paucispinis), the dataset can potentially even be expanded to include larval abundances derived from the historical formalin-preserved samples; this would be valuable given how many more decades back the formalin-preserved samples date than the ethanol-preserved samples.

In addition to the research described in this thesis, these data can be analyzed for several future studies. One could attempt a more in-depth and more contemporary spatiotemporal analysis; for the purpose of simplicity I restricted this study to statistical analyses that were established and straightforward to understand, but as a result I did not look at spatial variability at a station-bystation scale. For example, Thorson et al. (2015) used a novel multivariate approach - spatial factor analysis - to model distribution of 20 rockfish species off the U.S. West Coast simultaneously based off of trawl survey data from 2003 and 2012; this technique was found to be more accurate than analyzing individual 
species, as well as provided different insights into cross-correlations between species. Another aspect that will require further investigation is greater precision in determining natal locations of individual larvae, as this will determine whether or not the larvae actually originated from within the reserve. One way to address this is through utilizing otolith-based aging techniques (e.g. Hitchman et al. 2012) in conjunction with a regional oceanic modeling system (ROMS) (Weber et al. 2015) to attempt to account for potentially advective processes (i.e. currents) that may have influenced the direction toward and destination of where larvae were collected.

Additionally, assessing the regional fishing effort will help elucidate the impacts of the CCAs on targeted rockfish species and thereby expand upon the results of this study. Determining the intensity of fishing effort around the CCAs and whether or not there may even be substantial poaching within the CCAs can potentially explain why some targeted species have not seemed to recover.

In closing, this study has provided novel results with important local implications, for marine protected areas as a whole, for the southern California rockfish fishery, and has also set the groundwork for many more important studies to come.

\section{References}

1. HITCHMAN, S.M., N.B. Reyns, and A.R. Thompson. 2012. Larvae define spawning habitat of bocaccio rockfish Sebastes paucispinis within and around 
a large southern California marine reserve. Marine Ecology Progress Series 465: 227-242.

2. LOVE, M.S., Yoklavich, M.M., and L. Thorsteinson. 2002. The Rockfishes of the Northeast Pacific. University of California Press, Berkeley and Los Angeles, 404 pp.

3. THORSON, J.T., Scheuerell, M.D., Shelton, A.O., See, K.E., Skaug, H.J., and K. Kristensen. 2015. Spatial factor analysis: a new tool for estimating joint species distributions and correlations in species range. Methods in Ecology and Evolution 6:627-637.

4. WEBER, E.D., Chao, Y., Chai, F., and S. McClatchie. 2015. Transport patterns of Pacific sardine Sardinops sagax eggs and larvae in the California Current System. Deep-Sea Research I 100:127-139. 


\section{Appendix 1: Genetic Identification Protocol}

A. Tissue extraction:

1. DNA is extracted from 95 larvae by removing one eye from each larva and placing them into 95 PCR strip tubes (the 96th tube will be a negative control) each containing $150 \mu \mathrm{L}$ of $10 \%$ Chelex solution.

2. The strip tubes are heated in a PCR machine at $60{ }^{\circ} \mathrm{C}$ first for 20 minutes, and then at $100{ }^{\circ} \mathrm{C}$ for 25 minutes.

B. Cytochrome b amplification:

1. $3 \mu \mathrm{L}$ of supernatant (which contains the extracted DNA) from each strip tube is mixed in new strip tubes each with $7 \mu \mathrm{L}$ of a reagent mix containing the following:

- Milli-Q water,

- 10x Buffer (20 mM MgCl 2$)$,

- $10 \mu \mathrm{M}$ Glu-RF2-5' primer (Hyde and Vetter 2007),

- $10 \mu \mathrm{M}$ CB3-RF2-5' primer (Hyde et al. 2008),

- $20 \mathrm{mg} \mathrm{ml}^{-1}$ bovine serum albumen,

- $2 \mathrm{nM}$ deoxynucleotide triphosphates, and

- $\quad 5$ units $\mu \mathrm{L}^{-1}$ Taq polymerase.

2. The tubes containing the extracted DNA-reagent mix are heated in a PCR machine first at $92{ }^{\circ} \mathrm{C}$ for $2.5 \mathrm{~min}$, then for 45 cycles of the following:

1) $94{ }^{\circ} \mathrm{C}$ for $30 \mathrm{sec}$

2) $57{ }^{\circ} \mathrm{C}$ for $1.5 \mathrm{~min}$, and

3) $70{ }^{\circ} \mathrm{C}$ for $1.5 \mathrm{~min}$. 
Finally the tubes are brought to $72^{\circ} \mathrm{C}$ for $1.5 \mathrm{~min}$.

3. $3 \mu \mathrm{L}$ of PCR product from 7 designated wells and $3 \mu \mathrm{L}$ of the negative control are run on a $2 \%$ ethidium bromide-agarose gel at $115 \mathrm{~V}$ for 15 minutes, and the gel is visualized using an Alphaimager 2200 to determine success of the PCR. Success is indicated by strong bands in the lanes loaded with the 7 samples and absence of a band in the lane containing the negative control.

C. ExoSAP and sequencing reaction:

1. $5 \mu \mathrm{L}$ of each PCR product is mixed in a 96 -well plate with $2 \mu \mathrm{L}$ of ExoSAP-IT (USB Corp.) to remove extra primers and dNTPs.

2. The plate is heated in a PCR machine first at $37^{\circ} \mathrm{C}$ for $15 \mathrm{~min}$, and then at $80{ }^{\circ} \mathrm{C}$ for $15 \mathrm{~min}$.

3. $5 \mu \mathrm{L}$ of a reagent mix comprised of the following is added to each of the wells:

- Milli-Q water,

- 5x Buffer (10mM $\left.\mathrm{MgCl}_{2}\right)$,

- $\quad$ Big Dye v. 3.1 (Applied Biosystems), and

- $\quad 10 \mu \mathrm{M}$ CBinR3 primer (Gallagher and Heppell 2010)

4. The plate is heated in a PCR machine first at $92{ }^{\circ} \mathrm{C}$ for $3 \mathrm{~min}$, then for 34 cycles of the following:

1) $95^{\circ} \mathrm{C}$ for $5 \mathrm{sec}$,

2) $50{ }^{\circ} \mathrm{C}$ for $10 \mathrm{sec}$, and

3) $60{ }^{\circ} \mathrm{C}$ for $4 \mathrm{~min}$. 
Finally the plate is cooled to $8^{\circ} \mathrm{C}$ until it is taken to the cold room for the sequencing precipitation.

D. Sequencing precipitation:

1. $88 \mu \mathrm{L}$ of sequencing precipitate $\operatorname{mix}(0.1 \mathrm{M} \mathrm{NaOAc})$ is added to each well on the plate.

2. The plate is vortexed and placed in a $-80{ }^{\circ} \mathrm{C}$ freezer for $5 \mathrm{~min}$.

3. The plate is centrifuged at $3700 \mathrm{rpm}$ for 20 minutes, and the precipitate mix is poured out of the wells.

4. $150 \mu \mathrm{L}$ of $70 \%$ ethanol is added to and then poured out of each well.

5. $10 \mu \mathrm{L}$ of Formamide Hi-Di (Life Technologies) is added to each well.

6. The plate is heated in a PCR machine at $95^{\circ} \mathrm{C}$ for $5 \mathrm{~min}$.

E. Sequencing and identification:

1. The plate is sequenced using an Applied Biosystems-Hitachi 3730 DNA Analyzer.

2. Each sequence is quality-checked using Sequencher software (GeneCodes, Inc.) to look at nucleotide discrepancies among the sequences and determine whether the discrepancies were due to instrument error or represent genuine genetic differences.

3. The quality-checked sequences are input into Molecular Evolutionary Genetics Analysis (MEGA) software, which compares and matches the query sequences to master sequences for each rockfish species.

References 
1. HYDE, J.R., and R.D. Vetter. 2007. The origin, evolution, and diversification of rockfishes of the genus Sebastes (Cuvier). Molecular phylogenetics and evolution 44(2):790-811.

2. HYDE, J.R., Kimbrell, C.A., Budrick, J.E., Lynn, E.A., and R.D. Vetter. 2008. Cryptic speciation in the vermilion rockfish (Sebastes miniatus) and the role of bathymetry in the speciation process. Molecular Ecology 17(4):11221136.

3. GALLAGHER, M.B., and S.S. Heppell. 2010. Essential habitat identification for age- 0 rockfish along the central Oregon coast. Marine and Coastal Fisheries: Dynamics, Management, and Ecosystem Science 60-72. 
Appendix 2: Supplemental Tables and Figures 
Table A.1 Correlation coefficients of environmental variables with each other. 


\begin{tabular}{|l|c|c|c|c|}
\hline & Temp 100m & Salinity 100m & Oxygen 100m & Chl a 100m \\
\hline Temp 100m & - & -0.143 & 0.571 & -0.155 \\
\hline Salinity 100m & -0.143 & - & -0.525 & 0.093 \\
\hline Oxygen 100m & 0.571 & -0.525 & - & 0.080 \\
\hline Chl a 100m & -0.155 & 0.093 & 0.080 & - \\
\hline
\end{tabular}


Table A.2 Larval abundances (corrected for standard haul factor) of all rockfish species sequenced during the study. Species that have been historically targeted by recreational or commercial fisheries in the SCB are indicated in bold. 


\begin{tabular}{|c|c|c|c|c|c|c|c|c|c|c|c|c|c|c|c|c|}
\hline Species & 1998 & 1999 & 2000 & 2001 & 2002 & 2004 & 2005 & 2006 & 2007 & 2008 & 2009 & 2010 & 2011 & 2012 & 2013 & Total \\
\hline S. auriculatus & 0 & 0 & 0 & 0 & 0 & 0 & 0 & 0 & 9.13 & 0 & 0 & 0 & 0 & 4.32 & 0 & 13.45 \\
\hline S. aurora & 4.83 & 0 & 4.71 & 5.54 & 14.55 & 0 & 3.81 & 9.3 & 15.25 & 5.03 & 20.52 & 20.04 & 0 & 8.57 & 15.05 & 127.2 \\
\hline S. caurinus & 0 & 0 & 0 & 10.24 & 9.95 & 8.3 & 11.71 & 23.67 & 28.33 & 12.63 & 26.15 & 38.33 & 38.47 & 16.8 & 89.49 & 314.07 \\
\hline S. chlorostictus & 0 & 0 & 0 & 0 & 0 & 0 & 0 & 0 & 0 & 0 & 0 & 0 & 0 & 0 & 4.09 & 4.09 \\
\hline S. constellatus & 0 & 0 & 0 & 0 & 0 & 0 & 0 & 0 & 0 & 0 & 0 & 0 & 0 & 15.22 & 0 & 15.22 \\
\hline S. crameri & 0 & 0 & 0 & 0 & 0 & 0 & 0 & 0 & 0 & 0 & 0 & 0 & 0 & 0 & 0 & 0 \\
\hline S. crocotulus & 0 & 0 & 14.14 & 13.55 & 0 & 0 & 19.6 & 14.35 & 15.15 & 19.16 & 52.22 & 24.75 & 9.9 & 5 & 48.93 & 236.75 \\
\hline S. dalli & 0 & 0 & 0 & 0 & 0 & 0 & 0 & 0 & 0 & 0 & 0 & 0 & 8.91 & 0 & 0 & 8.91 \\
\hline S. diploproa & 33.39 & 4.12 & 23.83 & 4.85 & 4.53 & 0 & 32.08 & 36.95 & 15.39 & 24.11 & 10.41 & 0 & 35.56 & 0 & 29.08 & 254.3 \\
\hline S. elongatus & 0 & 0 & 0 & 0 & 24.37 & 0 & 14.07 & 0 & 15.66 & 0 & 0 & 18.21 & 8.03 & 24.1 & 8.57 & 113.01 \\
\hline S. ensifer & 74.99 & 4.17 & 41.16 & 13.75 & 14.69 & 0 & 4.93 & 51.86 & 25.05 & 4.81 & 111.14 & 56.02 & 31.51 & 28.79 & 30.5 & 493.37 \\
\hline S. entomelas & 4.1 & 0 & 0 & 25.03 & 5.11 & 0 & 9.28 & 22.5 & 9.73 & 24 & 49.4 & 119.8 & 26.86 & 0 & 43.7 & 339.51 \\
\hline S. flavidus & 0 & 0 & 0 & 0 & 0 & 0 & 0 & 0 & 0 & 0 & 0 & 9.9 & 9.24 & 5 & 9.96 & 34.1 \\
\hline S. gilli & 0 & 0 & 0 & 0 & 0 & 4.72 & 4.93 & 0 & 0 & 0 & 8.65 & 0 & 0 & 0 & 0 & 18.3 \\
\hline S. goode $i$ & 4.74 & 0 & 4.43 & 10.24 & 0 & 19.08 & 94.66 & 9.76 & 50.03 & 24.42 & 326.23 & 53.53 & 23.27 & 13.69 & 69.36 & 703.44 \\
\hline S. helvomaculatus & 0 & 0 & 0 & 0 & 0 & 0 & 0 & 8.9 & 0 & 0 & 0 & 0 & 0 & 9.68 & 0 & 18.58 \\
\hline S. hopkinsi & 60.56 & 200.83 & 292.93 & 630.04 & 279.76 & 350.45 & 233.53 & 807.13 & 300.58 & 446.33 & 375.49 & 1038.57 & 934.62 & 1461.05 & 1692.3 & 9104.17 \\
\hline S. jordani & 7.86 & 8.6 & 47 & 310.37 & 1554.55 & 45.95 & 332.94 & 747.7 & 655.39 & 666.05 & 249 & 253.01 & 246.26 & 1338.47 & 420.69 & 6883.84 \\
\hline S. levis & 0 & 0 & 4.33 & 4.59 & 9.49 & 0 & 13.38 & 9.61 & 19.49 & 13.88 & 15.18 & 25.21 & 13.89 & 14.27 & 17.29 & 160.61 \\
\hline S. macdonaldi & 0 & 0 & 0 & 0 & 0 & 0 & 3.86 & 4.66 & 0 & 0 & 0 & 0 & 0 & 0 & 4.09 & 12.61 \\
\hline S. melanostomus & 9.64 & 0 & 4.64 & 0 & 14.6 & 0 & 0 & 13.93 & 0 & 0 & 5.48 & 4.77 & 0 & 0 & 0 & 53.06 \\
\hline S. miniatus & 0 & 0 & 4.71 & 0 & 4.53 & 0 & 13.19 & 4.64 & 14.47 & 4.81 & 3.83 & 5.01 & 9.9 & 0 & 49.31 & 114.4 \\
\hline S. moseri & 0 & 3.64 & 0 & 9.17 & 10.08 & 9.44 & 30.22 & 23 & 15.27 & 33.84 & 23.22 & 21.55 & 25.55 & 109.49 & 58.1 & 372.57 \\
\hline
\end{tabular}




\begin{tabular}{|c|c|c|c|c|c|c|c|c|c|c|c|c|c|c|c|c|}
\hline Species & 1998 & 1999 & 2000 & 2001 & 2002 & 2004 & 2005 & 2006 & 2007 & 2008 & 2009 & 2010 & 2011 & 2012 & 2013 & Total \\
\hline S. mystinus & 0 & 12.92 & 4.72 & 98.08 & 9.7 & 46.27 & 155.32 & 4.66 & 137.51 & 108.47 & 77.92 & 181.7 & 184.09 & 54.66 & 428.84 & 1504.86 \\
\hline S. ovalis & 7.86 & 0 & 0 & 18.81 & 18.12 & 18.93 & 74.2 & 24.47 & 48.92 & 50.76 & 50.98 & 89.75 & 62.22 & 74.49 & 216.84 & 756.35 \\
\hline S. paucispinis & 0 & 0 & 31.47 & 46.61 & 35.15 & 137.01 & 140.03 & 65.07 & 114.43 & 120.89 & 170.21 & 99.39 & 113.48 & 88.79 & 88.18 & 1250.71 \\
\hline S. phillipsi & 0 & 0 & 0 & 0 & 0 & 0 & 4.37 & 0 & 5.52 & 10.21 & 5.48 & 0 & 0 & 0 & 7.2 & 32.78 \\
\hline S. rastrelliger & 4.1 & 0 & 0 & 0 & 0 & 0 & 0 & 0 & 0 & 0 & 4.96 & 0 & 0 & 0 & 9.75 & 18.81 \\
\hline S. rosaceus & 0 & 0 & 0 & 0 & 0 & 9.49 & 4.41 & 17.32 & 4.45 & 0 & 0 & 5.15 & 22.11 & 57.15 & 9.67 & 129.75 \\
\hline S. rosenblatti & 0 & 0 & 0 & 0 & 0 & 0 & 0 & 0 & 0 & 0 & 0 & 4.76 & 0 & 0 & 0 & 4.76 \\
\hline S. ruberrimus & 0 & 0 & 0 & 0 & 0 & 0 & 0 & 0 & 0 & 0 & 0 & 0 & 0 & 5.07 & 4.87 & 9.94 \\
\hline S. rubrivinctus & 0 & 0 & 0 & 0 & 0 & 0 & 4.47 & 0 & 0 & 0 & 0 & 0 & 0 & 0 & 0 & 4.47 \\
\hline S. rufinanus & 0 & 0 & 0 & 5.06 & 9.06 & 0 & 17.75 & 0 & 9.85 & 5.03 & 0 & 13.36 & 27.04 & 46.53 & 3.87 & 137.55 \\
\hline S. rufus & 87.28 & 0 & 17.83 & 19.2 & 120.19 & 47.35 & 98.01 & 51.64 & 71.04 & 18.5 & 59.22 & 95.71 & 84.55 & 71.05 & 130.57 & 972.14 \\
\hline S. saxicola & 19.06 & 15.4 & 64.64 & 37.13 & 48.43 & 14.03 & 151.42 & 87.3 & 62.22 & 32.11 & 126.11 & 54.17 & 47.2 & 82.74 & 166.33 & 1008.29 \\
\hline S. semicinctus & 0 & 0 & 8.46 & 0 & 14.66 & 0 & 26.22 & 129.49 & 0 & 0 & 0 & 57.93 & 83.83 & 994.05 & 41.88 & 1356.52 \\
\hline S. serranoides & 3.93 & 0 & 0 & 13.32 & 14.16 & 13.02 & 60.88 & 9.21 & 27.6 & 9.88 & 34.68 & 78.91 & 21.65 & 34.67 & 94.73 & 416.64 \\
\hline S. simulator & 0 & 0 & 0 & 0 & 0 & 0 & 0 & 0 & 0 & 0 & 0 & 0 & 0 & 10.88 & 4.43 & 15.31 \\
\hline S. wilsoni & 11.79 & 22.65 & 67.06 & 56.98 & 67.83 & 127.89 & 80.04 & 163.87 & 282.88 & 121.07 & 152.48 & 281.2 & 180.56 & 74.88 & 115.95 & 1807.13 \\
\hline
\end{tabular}


Table A.3 Slope estimates, standard errors, z-values, and p-values of each of the study species' relationship with temperature, oxygen, salinity, and chlorophyll measured at $100 \mathrm{~m}$ depth. 


\begin{tabular}{|l|c|c|c|c|}
\hline S. caurinus & Estimate & Std. Error & z-value & p-value \\
\hline Temperature & -0.556 & 0.339 & -1.640 & 0.101 \\
\hline Salinity & 0.773 & 2.059 & 0.376 & 0.707 \\
\hline Oxygen & 0.376 & 0.669 & 0.562 & 0.574 \\
\hline Chlorophyll a & 0.464 & 0.214 & 2.169 & 0.030 \\
\hline
\end{tabular}

\begin{tabular}{|l|c|c|c|c|}
\hline S. entomelas & Estimate & Std. Error & z-value & p-value \\
\hline Temperature & -0.855 & 0.306 & -2.796 & 0.005 \\
\hline Salinity & -1.294 & 1.455 & -0.883 & 0.377 \\
\hline Oxygen & 0.516 & 0.583 & 0.885 & 0.376 \\
\hline Chlorophyll a & 0.001 & 0.242 & 0.002 & 0.998 \\
\hline
\end{tabular}

\begin{tabular}{|l|c|c|c|c|}
\hline S. goodei & Estimate & Std. Error & z-value & p-value \\
\hline Temperature & -0.281 & 0.310 & -0.907 & 0.364 \\
\hline Salinity & -3.297 & 1.311 & -2.515 & 0.012 \\
\hline Oxygen & -0.836 & 0.614 & -1.363 & 0.173 \\
\hline Chlorophyll a & -0.095 & 0.336 & -0.282 & 0.778 \\
\hline
\end{tabular}

\begin{tabular}{|l|c|c|c|c|}
\hline S. levis & Estimate & Std. Error & z-value & p-value \\
\hline Temperature & -0.172 & 0.288 & -0.597 & 0.551 \\
\hline Salinity & 1.198 & 1.972 & 0.608 & 0.543 \\
\hline Oxygen & 0.250 & 0.695 & 0.360 & 0.719 \\
\hline Chlorophyll a & 0.341 & 0.241 & 1.411 & 0.158 \\
\hline
\end{tabular}

\begin{tabular}{|l|c|c|c|c|}
\hline S. mystinus & Estimate & Std. Error & z-value & p-value \\
\hline Temperature & -1.090 & 0.262 & -4.157 & 0.000 \\
\hline Salinity & -0.351 & 1.329 & -0.264 & 0.792 \\
\hline Oxygen & 1.035 & 0.483 & 2.142 & 0.032 \\
\hline Chlorophyll a & 0.250 & 0.179 & 1.396 & 0.163 \\
\hline
\end{tabular}

\begin{tabular}{|l|c|c|c|c|}
\hline S. ovalis & Estimate & Std. Error & z-value & p-value \\
\hline Temperature & -0.460 & 0.233 & -1.972 & 0.049 \\
\hline Salinity & -0.492 & 1.281 & -0.384 & 0.701 \\
\hline Oxygen & 0.179 & 0.479 & 0.373 & 0.709 \\
\hline Chlorophyll a & 0.111 & 0.199 & 0.554 & 0.579 \\
\hline
\end{tabular}

\begin{tabular}{|l|c|c|c|c|}
\hline S. paucispinis & Estimate & Std. Error & z-value & p-value \\
\hline Temperature & -0.758 & 0.204 & -3.713 & 0.000 \\
\hline Salinity & -1.312 & 0.981 & -1.338 & 0.181 \\
\hline Oxygen & 0.376 & 0.400 & 0.943 & 0.346 \\
\hline Chlorophyll a & -0.038 & 0.180 & -0.209 & 0.835 \\
\hline
\end{tabular}

\begin{tabular}{|l|c|c|c|c|}
\hline S. rufus & Estimate & Std. Error & z-value & p-value \\
\hline Temperature & -0.129 & 0.161 & -0.803 & 0.422 \\
\hline Salinity & 0.253 & 0.967 & 0.262 & 0.793 \\
\hline Oxygen & 0.545 & 0.415 & 1.315 & 0.188 \\
\hline Chlorophyll a & -0.203 & 0.218 & -0.929 & 0.353 \\
\hline
\end{tabular}

\begin{tabular}{|l|c|c|c|c|}
\hline S. serranoides & Estimate & Std. Error & z-value & p-value \\
\hline Temperature & -0.633 & 0.285 & -2.223 & 0.026 \\
\hline Salinity & -1.122 & 1.413 & -0.794 & 0.427 \\
\hline Oxygen & 0.249 & 0.557 & 0.447 & 0.655 \\
\hline Chlorophyll a & 0.143 & 0.219 & 0.650 & 0.516 \\
\hline
\end{tabular}




\begin{tabular}{|l|c|c|c|c|}
\hline S. ensifer & Estimate & Std. Error & z-value & p-value \\
\hline Temperature & 0.036 & 0.146 & 0.246 & 0.805 \\
\hline Salinity & 3.200 & 1.314 & 2.435 & 0.015 \\
\hline Oxygen & 0.358 & 0.476 & 0.752 & 0.452 \\
\hline Chlorophyll a & -0.423 & 0.294 & -1.436 & 0.151 \\
\hline
\end{tabular}

\begin{tabular}{|l|c|c|c|c|}
\hline S. hopkinsi & Estimate & Std. Error & z-value & p-value \\
\hline Temperature & -0.198 & 0.131 & -1.508 & 0.132 \\
\hline Salinity & 0.067 & 0.806 & 0.083 & 0.934 \\
\hline Oxygen & -0.492 & 0.330 & -1.489 & 0.136 \\
\hline Chlorophyll a & 0.266 & 0.158 & 1.683 & 0.092 \\
\hline
\end{tabular}

\begin{tabular}{|l|c|c|c|c|}
\hline S. jordani & Estimate & Std. Error & z-value & p-value \\
\hline Temperature & -0.022 & 0.147 & -0.146 & 0.884 \\
\hline Salinity & -1.257 & 0.831 & -1.513 & 0.130 \\
\hline Oxygen & -1.301 & 0.364 & -3.575 & 0.000 \\
\hline Chlorophyll a & 0.470 & 0.167 & 2.818 & 0.005 \\
\hline
\end{tabular}

\begin{tabular}{|l|c|c|c|c|}
\hline S. moseri & Estimate & Std. Error & z-value & p-value \\
\hline Temperature & -0.687 & 0.283 & -2.431 & 0.015 \\
\hline Salinity & -0.266 & 1.558 & -0.171 & 0.865 \\
\hline Oxygen & 0.937 & 0.625 & 1.501 & 0.133 \\
\hline Chlorophyll a & -1.444 & 0.615 & -2.349 & 0.019 \\
\hline
\end{tabular}

\begin{tabular}{|l|c|c|c|c|}
\hline S. saxicola & Estimate & Std. Error & z-value & p-value \\
\hline Temperature & -0.140 & 0.170 & -0.826 & 0.409 \\
\hline Salinity & -0.837 & 0.947 & -0.884 & 0.377 \\
\hline Oxygen & -0.540 & 0.399 & -1.354 & 0.176 \\
\hline Chlorophyll a & 0.267 & 0.174 & 1.536 & 0.125 \\
\hline
\end{tabular}

\begin{tabular}{|l|c|c|c|c|}
\hline S. semicinctus & Estimate & Std. Error & z-value & p-value \\
\hline Temperature & 0.165 & 0.285 & 0.577 & 0.564 \\
\hline Salinity & -1.926 & 1.441 & -1.336 & 0.181 \\
\hline Oxygen & -1.229 & 0.586 & -2.096 & 0.036 \\
\hline Chlorophyll a & 0.570 & 0.223 & 2.552 & 0.011 \\
\hline
\end{tabular}

\begin{tabular}{|l|c|c|c|c|}
\hline S. wilsoni & Estimate & Std. Error & z-value & p-value \\
\hline Temperature & -0.773 & 0.195 & -3.971 & 0.000 \\
\hline Salinity & -0.759 & 0.996 & -0.762 & 0.446 \\
\hline Oxygen & 0.137 & 0.385 & 0.356 & 0.722 \\
\hline Chlorophyll a & -0.036 & 0.175 & -0.207 & 0.836 \\
\hline
\end{tabular}


Figure A.1 Histograms of select species' abundances used to assess for outliers in the data. 


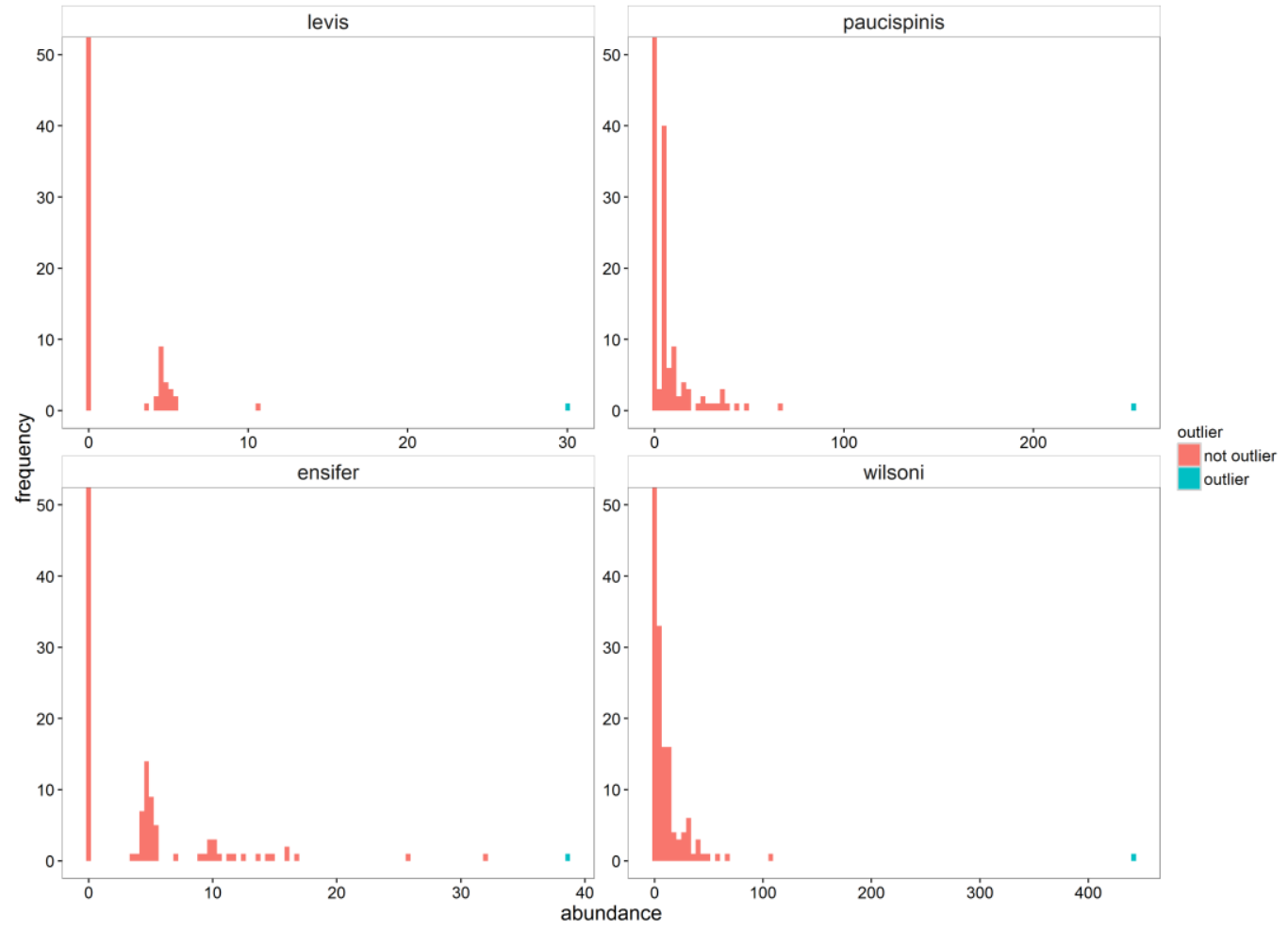


Figure A.2 Plots of z-values for Moran's I to assess spatial autocorrelation for residuals of the environmental logistic models. Red points indicate nonsignificance. 


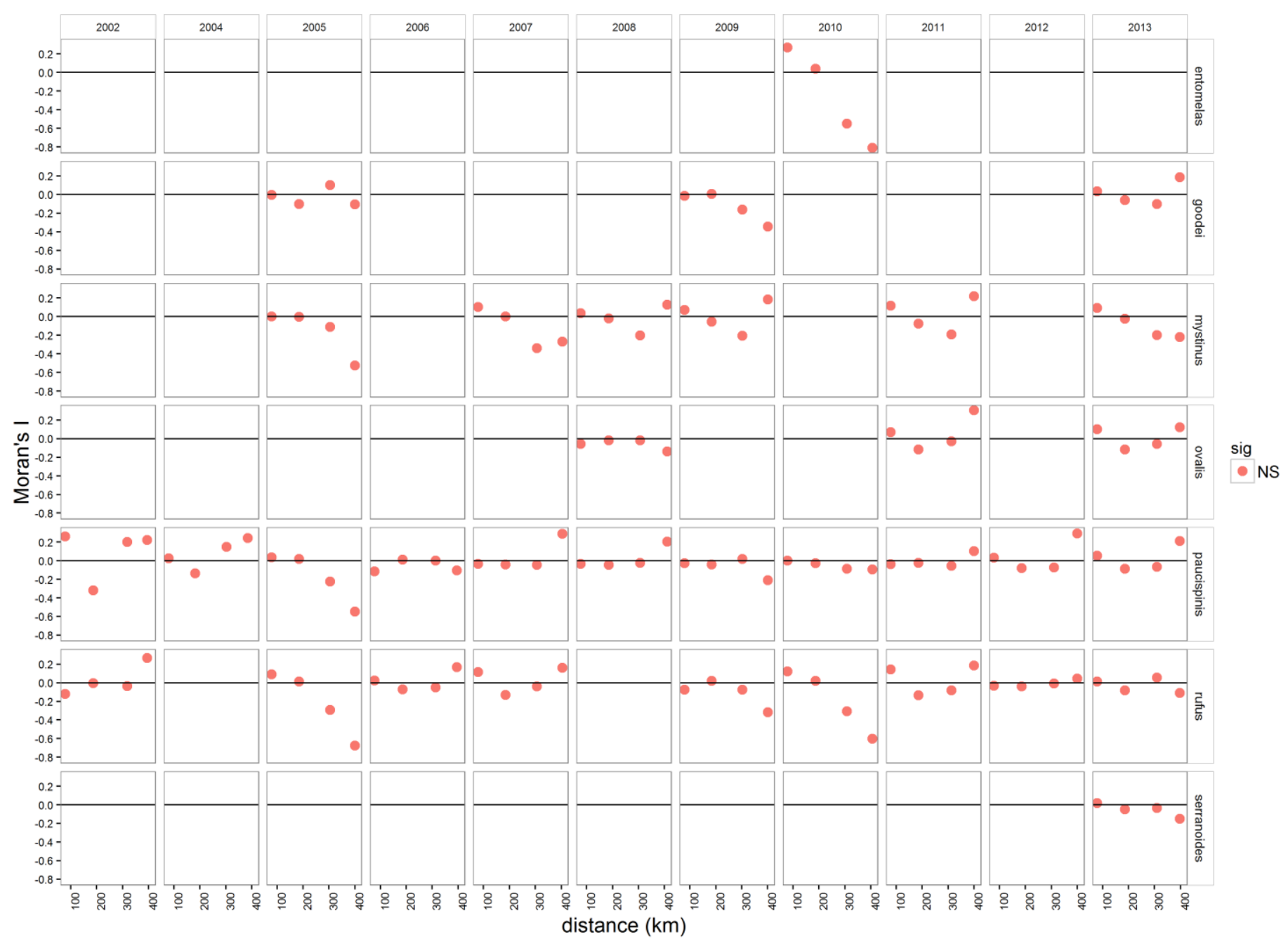




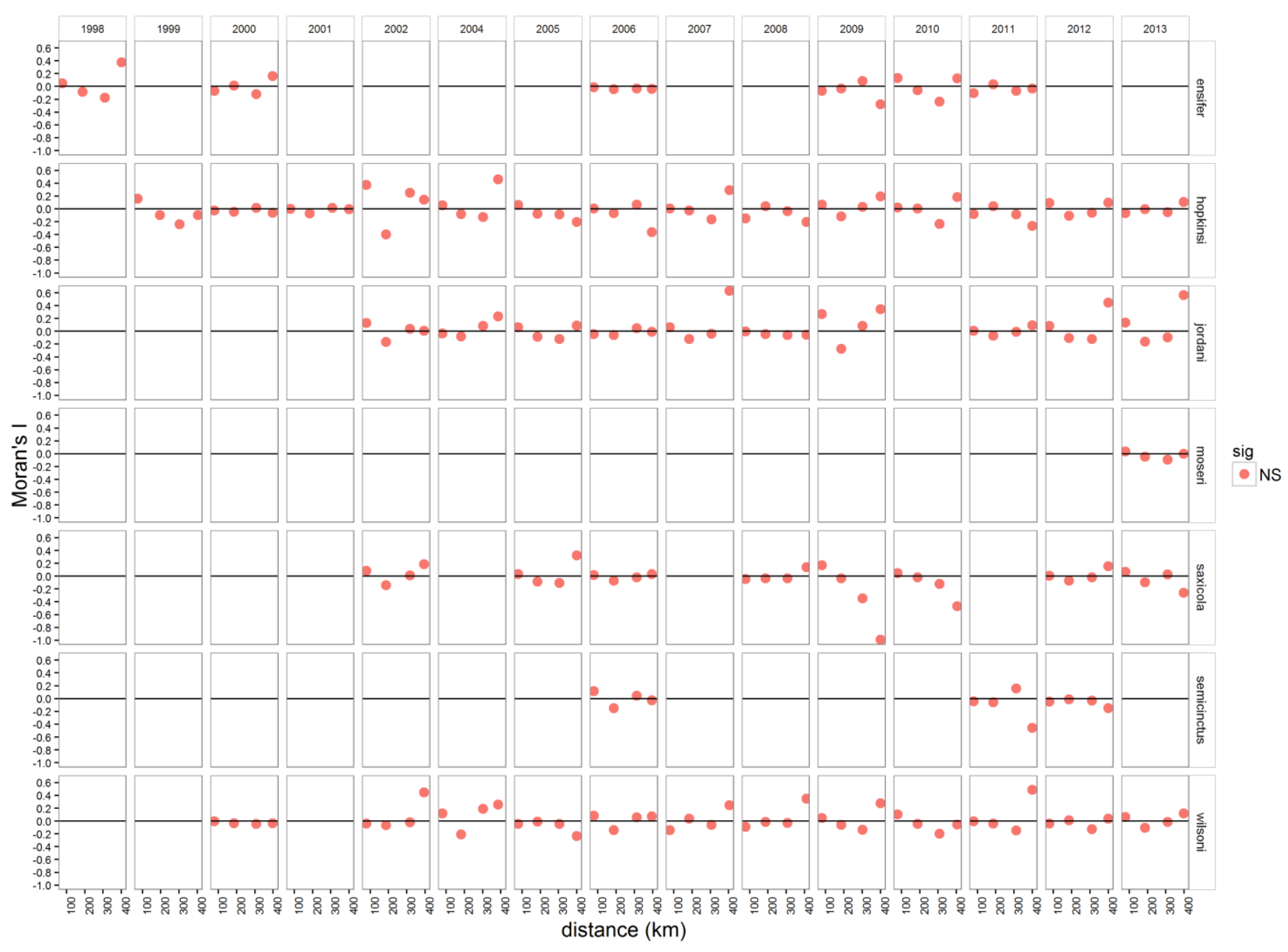


Figure A.3 Plots of the temporal autocorrelation function for residuals of the environmental logistic models with a year covariate included. 


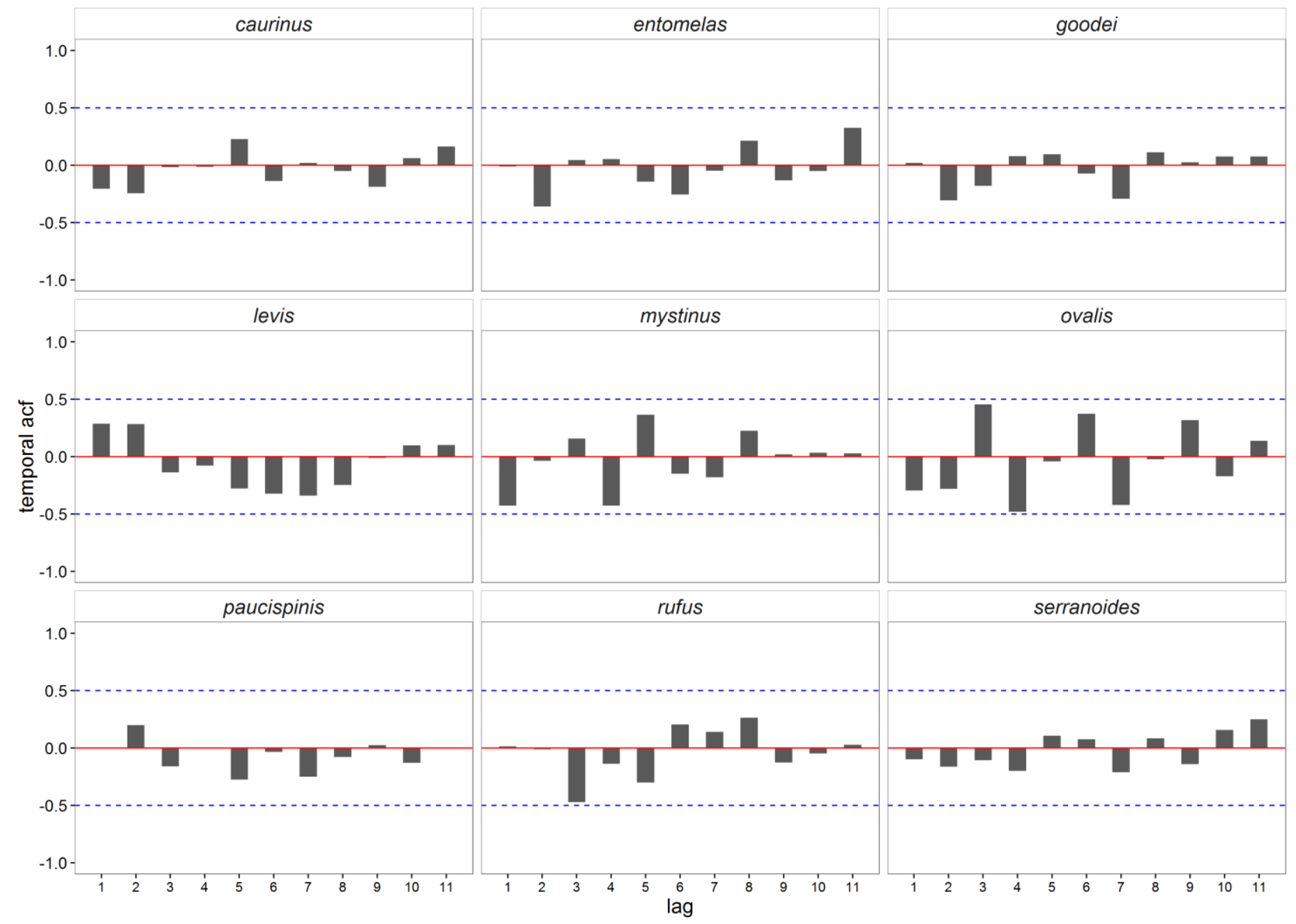




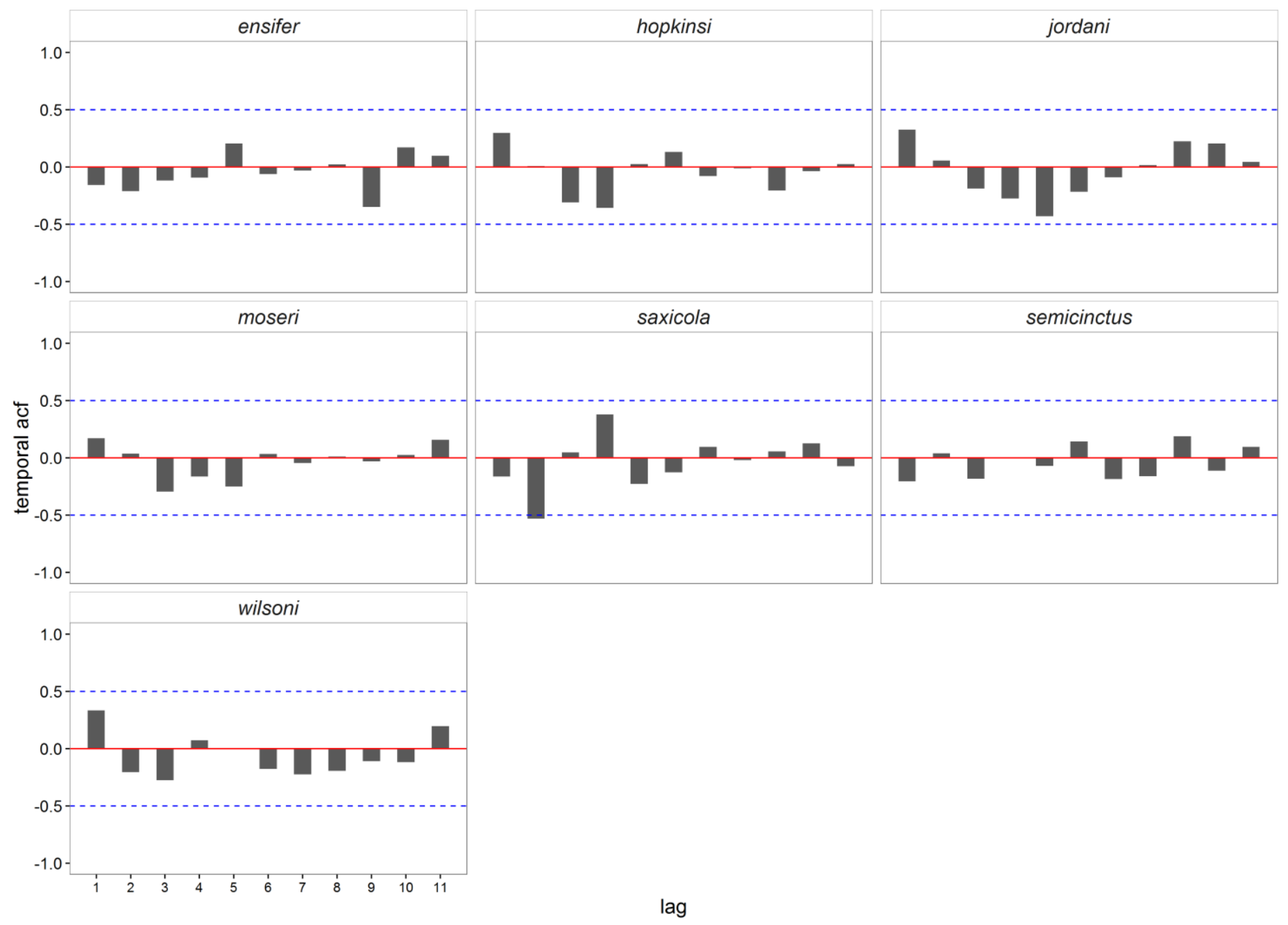

흐 
Figure A.4 Visualization of two-way Bray-Curtis cluster analysis to determine which non-CCA stations to select for analyses based on similar environmental parameters. Paired stations are highlighted in yellow. 


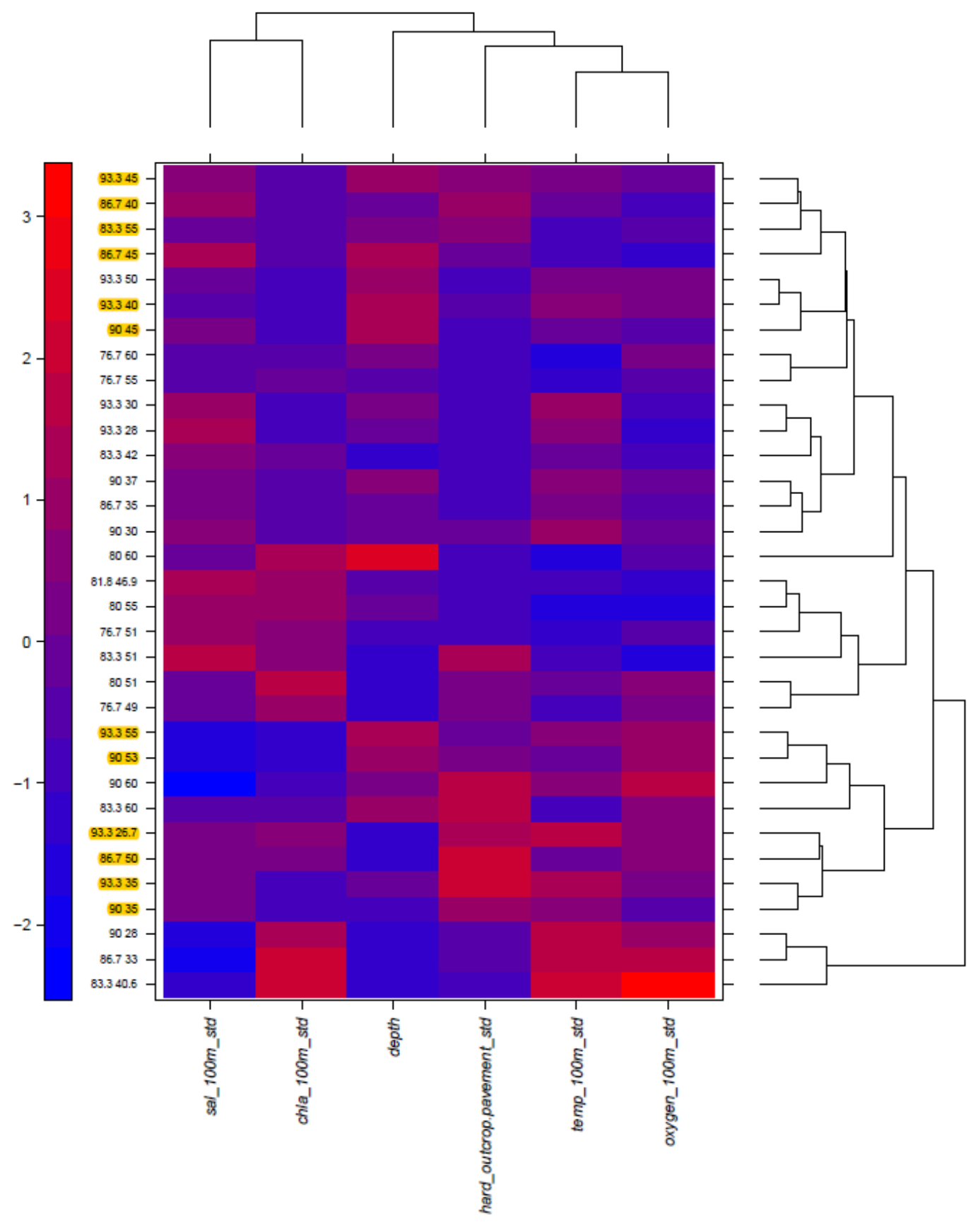


Figure A.5 Delta mean abundances of all rockfish species identified over time. Species that both met the abundance threshold of the study as well as displayed significant increases are described in Fig 2.1 and 2.2. 

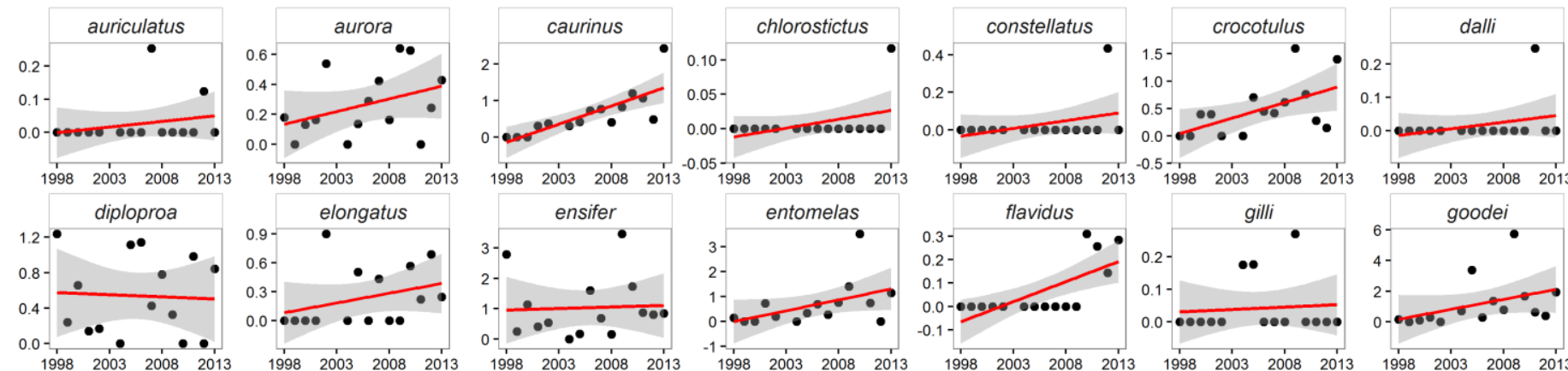

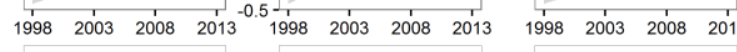
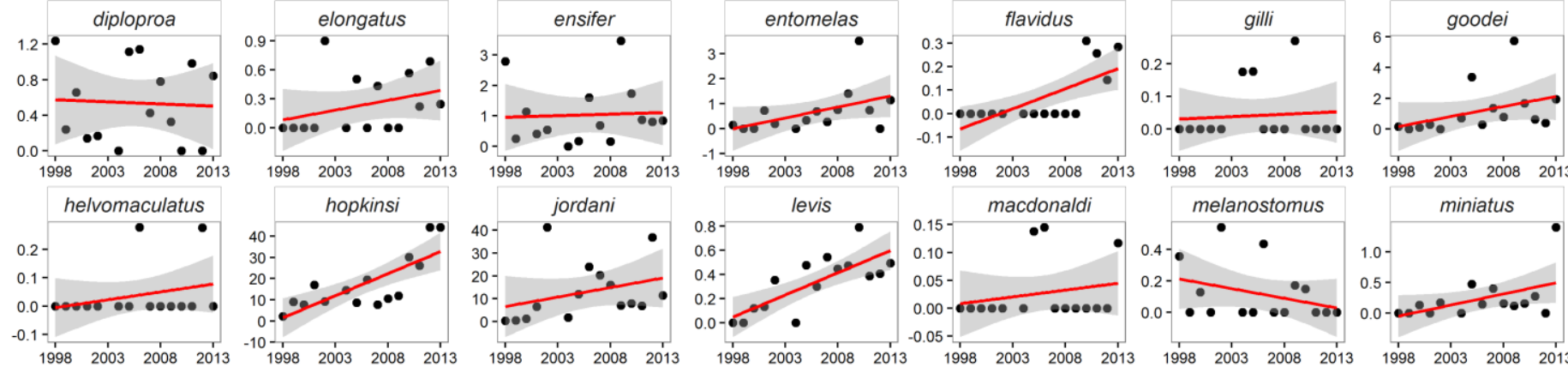

$199820032008 \quad 2013$

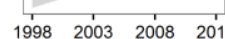

$\begin{array}{llll}1998 & 2003 & 2008 \quad 2013\end{array}$
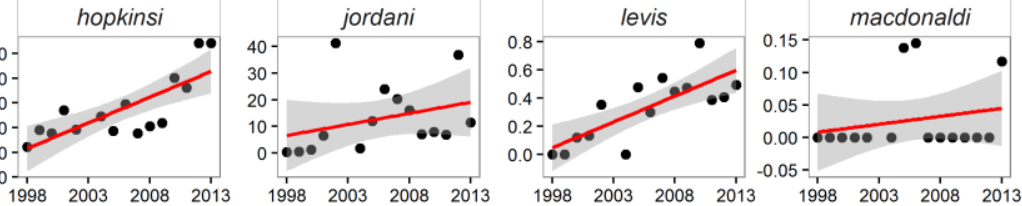

melanostomus

miniatus
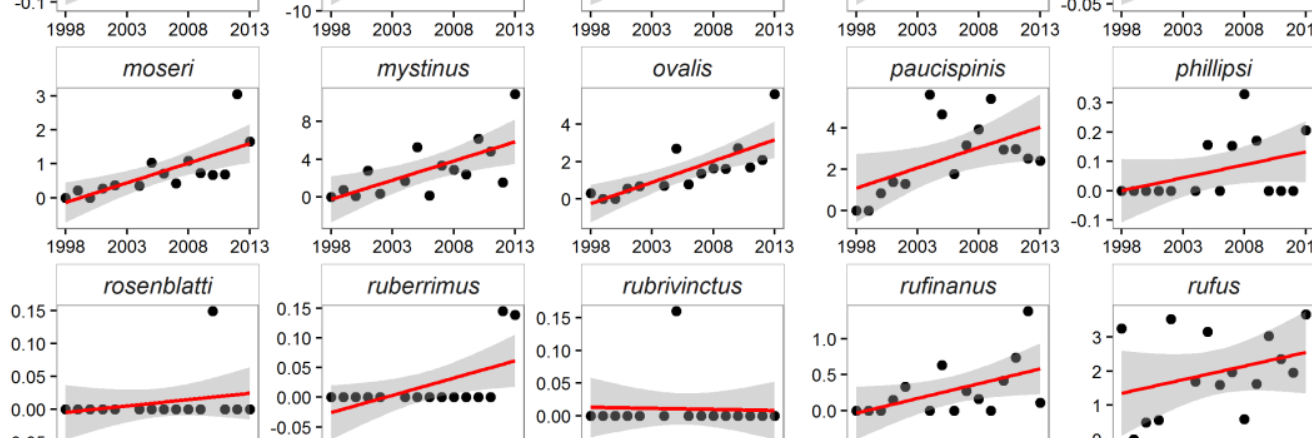

$0.2 \div-0.000 .000$

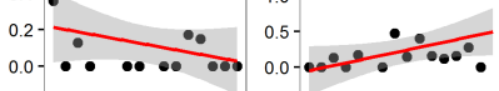

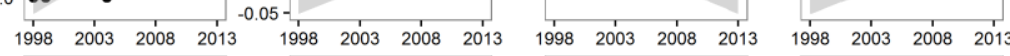

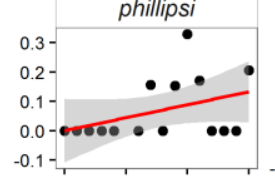

rastrelliger
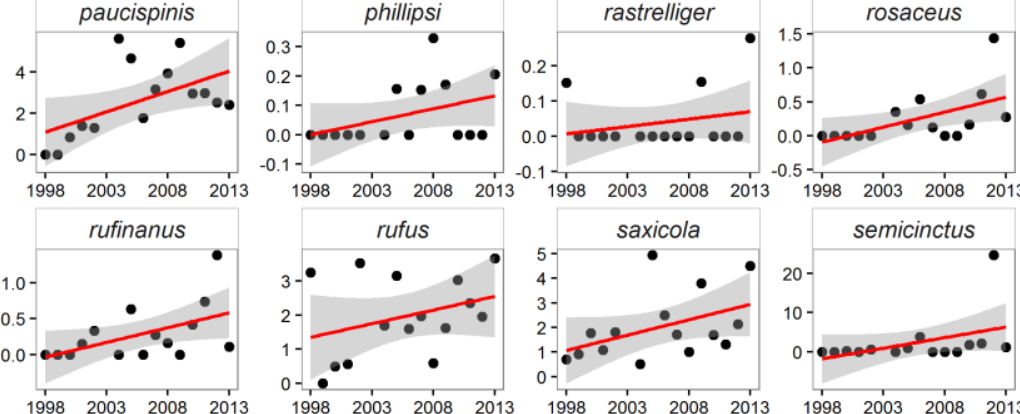

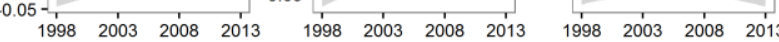



$\begin{array}{llll}1998 & 2003 & 2008 & 2013\end{array}$

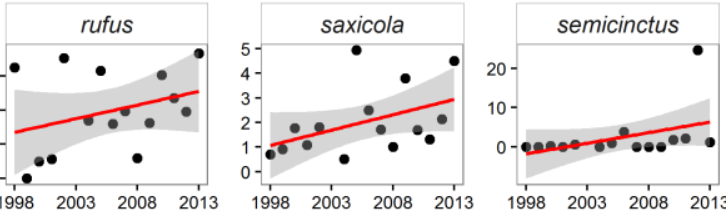

$\begin{array}{llllllllllll}1998 & 2003 & 2008 & 2013 & 1998 & 2003 & 2008 & 2013 & 1998 & 2003 & 2008 & 2013\end{array}$ 
Figure A.6 Logistic plots showing probability of presence of rockfish species under different temperature conditions. 

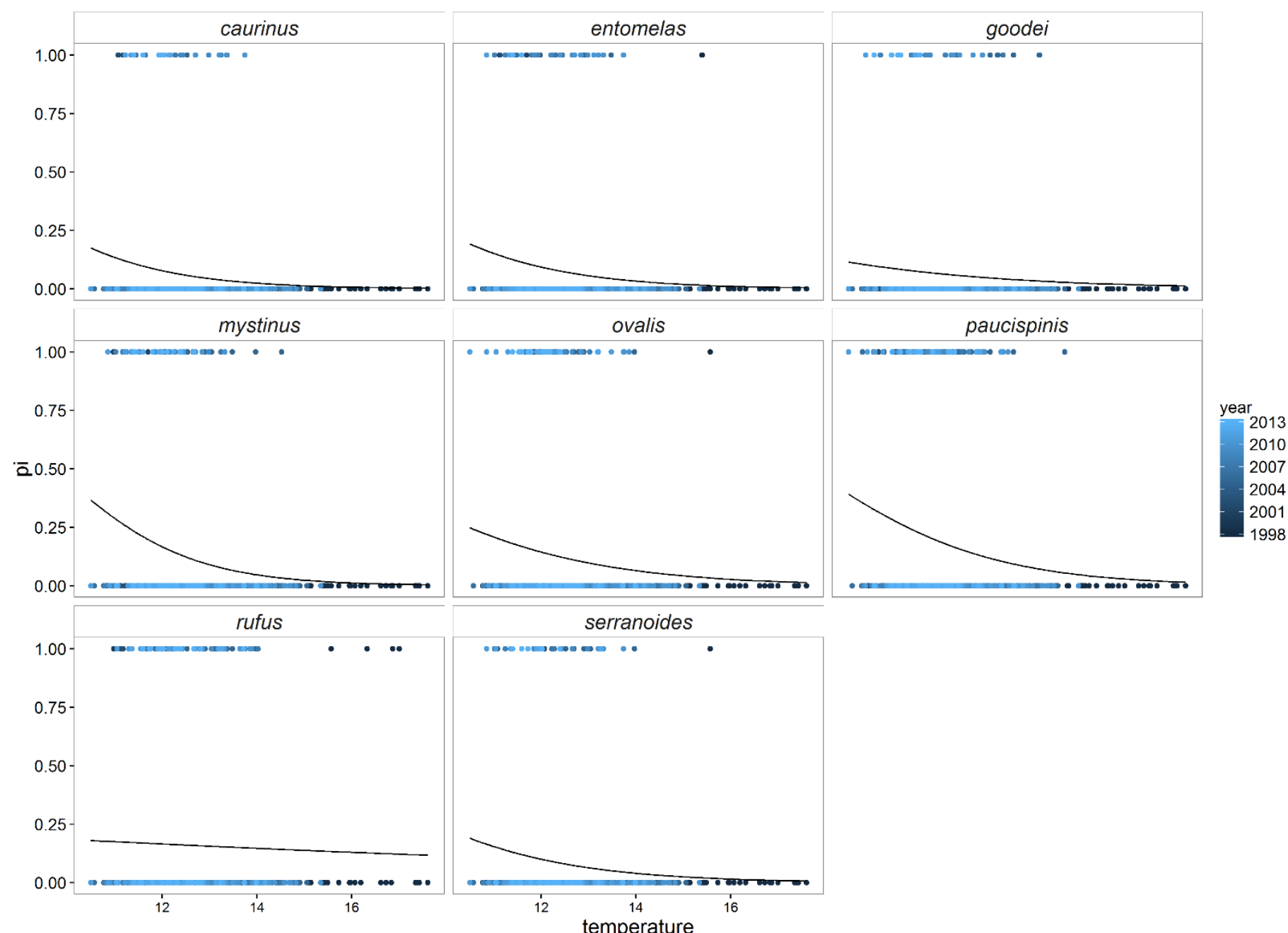


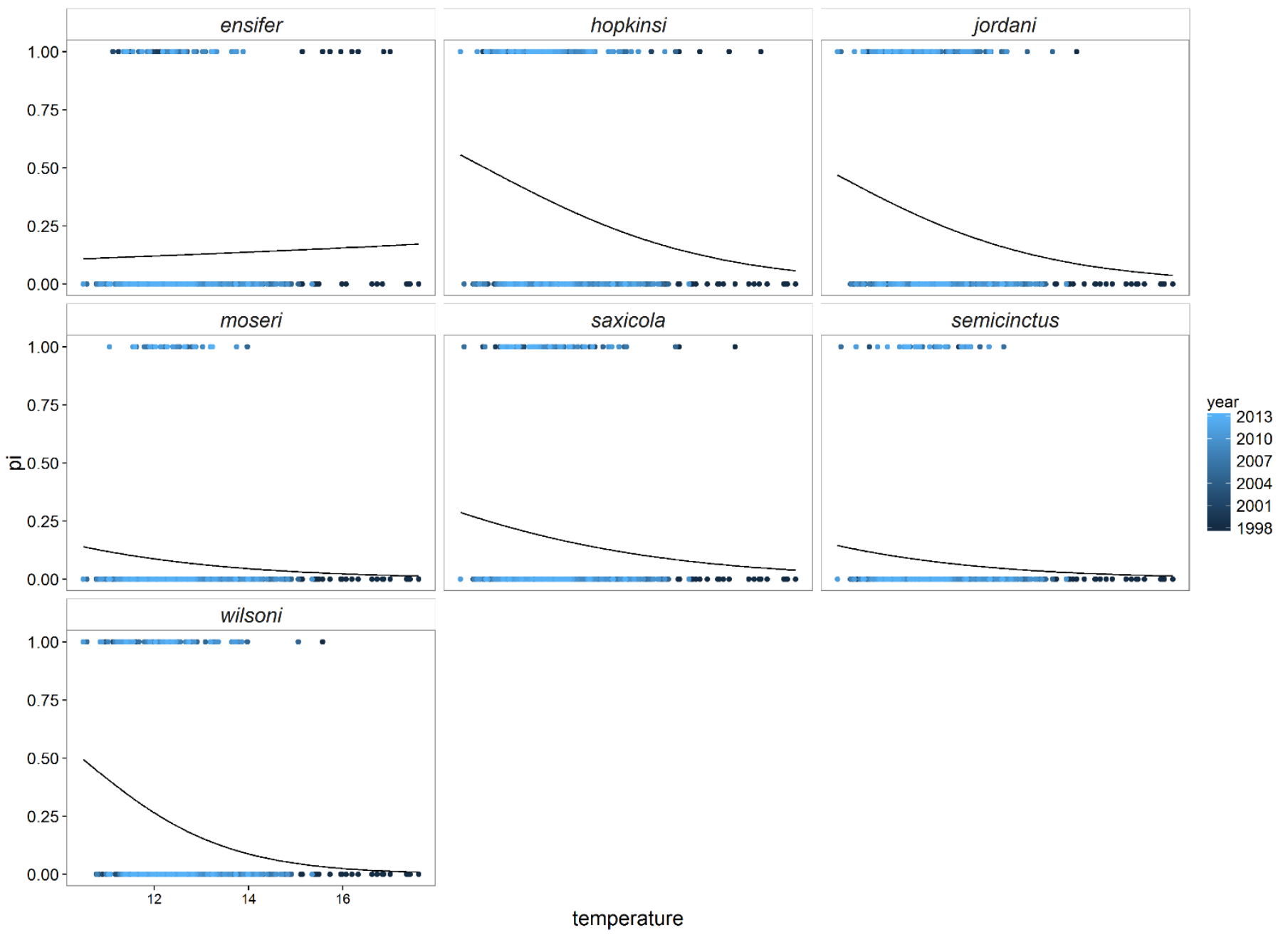




\section{Appendix 3: R packages used for analysis and plotting}

The following R packages were used in this paper: data.table (Dowle et al. 2015), fishmethods (Nelson 2016), ggdendro (de Vries and Ripley 2016), ggmap (Kahle and Wickham 2013), ggplot2 (Wickham 2009), lattice (Sarkar 2008), latticeExtra (Sarkar and Andrews 2016), mapproj (Mcllroy et al. 2015), maptools (Bivand and Lewin-Koh 2016), MASS (Venables and Ripley 2002), ncf (Bjornstad 2013), PBSmapping (Schnute et al. 2015), plyr (Wickham 2011), png (Urbanek 2013), reshape2 (Wickham 2007), rgdal (Bivand et al. 2016), rgeos (Bivand and Rundel 2016), sp (Bivand et al. 2013), spatstat (Baddeley et al. 2015), vegan (Oksanen et al. 2016), and xtractomatic (Mendelssohn 2016). 